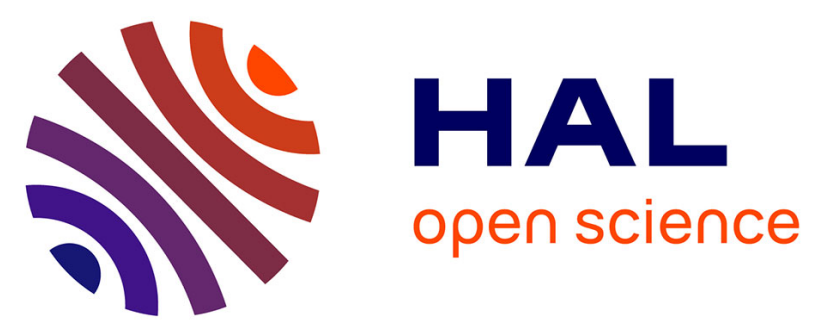

\title{
An original structural fold underlies the multitask P1, a silencing suppressor encoded by the Rice yellow mottle virus
}

\author{
Vianney Poignavent, François Hoh, Guillaume Terral, Yang Yinshan,
} François-Xavier Gillet, Jeong-Hyeon Kim, Frédéric Allemand, Eric Lacombe, Christophe Brugidou, Sarah Cianférani, et al.

\section{To cite this version:}

Vianney Poignavent, François Hoh, Guillaume Terral, Yang Yinshan, François-Xavier Gillet, et al.. An original structural fold underlies the multitask P1, a silencing suppressor encoded by the Rice yellow mottle virus. 2020. hal-03076418

\author{
HAL Id: hal-03076418 \\ https://hal.science/hal-03076418
}

Preprint submitted on 16 Dec 2020

HAL is a multi-disciplinary open access archive for the deposit and dissemination of scientific research documents, whether they are published or not. The documents may come from teaching and research institutions in France or abroad, or from public or private research centers.
L'archive ouverte pluridisciplinaire HAL, est destinée au dépôt et à la diffusion de documents scientifiques de niveau recherche, publiés ou non, émanant des établissements d'enseignement et de recherche français ou étrangers, des laboratoires publics ou privés. 
Title: An original structural fold underlies the multitask P1, a silencing suppressor encoded by the Rice yellow mottle virus

Vianney Poignavent ${ }^{1,5}$, François $\mathrm{Hoh}^{2,3 *}$, Guillaume Terral ${ }^{4, *}$, Yang Yinshan ${ }^{2,3}$, François-Xavier Gillet $^{1,6}$, Jeong Yeong Kim ${ }^{1}$, Frédéric Allemand ${ }^{2,3}$, Eric Lacombe ${ }^{1}$, Christophe Brugidou ${ }^{1}$, Sarah Cianferani ${ }^{4}$, Hélène Déméné ${ }^{2,3,8}$ and Florence Vignols ${ }^{1,7,8}$

${ }^{1}$ IPME, Université de Montpellier, IRD, CIRAD, Montpellier, France

${ }^{2}$ Centre de Biochimie Structurale (CBS), INSERM, CNRS, Univ Montpellier, Montpellier, France

${ }^{3}$ BCM, Univ. Montpellier, CNRS, INSERM, Montpellier, France.

${ }^{4}$ Laboratoire de Spectrométrie de Masse BioOrganique (LSMBO), Université de Strasbourg, IPHC, Strasbourg, France, and CNRS, UMR7178, Strasbourg, France

${ }^{5}$ Present address: IBMP, CNRS, Université de Strasbourg, Strasbourg, France

${ }^{6}$ Present address: Laboratoire de Physiologie Cellulaire et Végétale, Institut de Biosciences et Biotechnologies de Grenoble, CNRS, CEA, INRA, Université Grenoble Alpes, Grenoble, France.

${ }^{7}$ Present address: BPMP, CNRS, INRAE, Montpellier SupAgro, Univ Montpellier, Montpellier, France

*These authors contributed equally to the work

${ }^{\S}$ Co-corresponding authors, E-mails: florence.vignols@ supagro.fr ; helene.demene@ cbs.cnrs.fr

\section{Summary}

The Rice Yellow Mottle sobemovirus (RYMV) belongs to the most damaging pathogens devastating rice fields in Africa. P1, a key protein for RYMV, was reported as a potent RNAi suppressor counteracting RNA silencing in plant reporter systems. Here we describe the complete 3D structure and dynamics of P1. Its N-terminal region contains ZnF1, a structural CCCC-type zinc finger strongly affine to zinc and a prominent short helix, rendering this region poorly amenable to structural changes. P1 C-terminal region contains $\mathrm{ZnF}$ 2, an atypical $\mathrm{HCHC}$-type $\mathrm{ZnF}$ that does not belong to any existing class of $\mathrm{Zn}$ finger proteins. $\mathrm{ZnF} 2$ appeared much less affine to zinc and more sensitive to oxidizing environments than $\mathrm{ZnF1}$, and may serve as a sensor of plant redox status. We also identified key residues essential for RYMV infectivity and spread in rice tissues through their participation in P1 oligomerization and folding.

Altogether, our results provide the first complete structure of a rice antiviral silencing suppressor and highlight P1 structural properties that may serve RYMV functions to infect and invade the host plant. 


\section{Introduction}

Despite their rudimentary genome that encodes little proteins to assume their host life cycle, viruses have to rapidly establish complex interactions with host cellular machinery to guarantee successful infection. Usually RNA viruses present smaller genomes compared to DNA viruses, their genomes being under pressure for genome compression due to high mutation rate during viral replication (Holmes, 2003; Belshaw et al, 2007). At the same time, keeping a small size genome ensures the formation of smaller virions, which requires a minimal number of coat proteins (CP) for virion formation, thus maximizing virus production in host cells (Ben-Shaul \& Gelbart, 2015). RNA viruses have evolved different mechanisms to multiply viral functions while maintaining the size of their genome, which is considered as creation of genomic novelty from a single nucleic acids sequence. At the RNA level, splicing, leaky scanning, overlapping ORF, sub-genomic RNA and ribosomal frame shift are major pathways allowing production of different proteins from only a single sequence (Löwer et al, 1995; Brierley, 1995; Xu et al, 2001; Baril \& Brakier-Gingras, 2005; Dreher \& Miller, 2006; Belshaw et al, 2007; Sztuba-Solińska et al, 2011; Firth \& Brierley, 2012). On the other hand, viruses trend to use one protein for different functions, thus multiplying viral functions while keeping the number of proteins constant. Because of cumulative functions, those proteins are also referred as multifunctional. A multifunctional protein often presents conformational flexibility and intrinsic disorders to ensure different viral functions (Rantalainen et al, 2011; Plisson et al, 2003; Xue et al, 2010) or presents multi-domains structure, each domain carrying a distinct function (Deng et al, 2015; Sorel et al, 2014; Valli et al, 2018).

Plant viruses replicate in prime infected area, and rapidly spread in surrounding cells until they reach vascular tissues to establish systemic infection. Replication of RNA viruses is ensured by their viral RNA dependent RNA polymerase (RdRp), which often occurs in virus-modified membrane structures (Heinlein, 2015). Viral progeny moves intra-cellularly and cell-to-cell through plasmodesmata by highjacking cellular machinery with viral encoded movement protein (MP) (Carrington et al, 1996; Waigmann et al, 2004; Heinlein, 2015). No extensive similarity of MP sequences or molecular mechanism involved in virus transport has been found, each virus shows MP's singularity and mode of action (Taliansky et al, 2008; Verchot-Lubicz et al, 2010; Harries \& Ding, 2011). Nevertheless, to initiate systemic infection, viruses have to overcome sophisticated defense mechanisms set up by host plants such as RNA interference (RNAi) based on small interfering RNA (siRNA). RNAi is the main cellular mechanism involved in plant protection against invading RNA viruses (Pumplin et al., 2013). Viral dsRNA replicative intermediates or structured RNA genomes elicit cleavage by Dicer-like (DCL4) or its surrogate DCL2 to release 21 to 24 nts siRNA. siRNAs are loaded on Argonaute 1 (AGO1) or AGO2 to target viral RNA genome cleavage. To counteract this major defense mechanism plant RNA viruses have evolved viral suppressors of RNA silencing (VSR) capable of preventing RNAi triggered immunity (Pumplin \& Voinnet, 2013; Csorba et al, 2015). VSRs were intensively studied during last decades due to their crucial role in viral cycle and their 
potential for antiviral targeting molecules (Ghosh et al, 2017). Like MPs, VSR proteins do not show sequences or molecular organization similarities and often present different mechanisms to interfere with RNAi (Lakatos et al, 2006; Zhang et al, 2006; Bortolamiol et al, 2007; Pumplin \& Voinnet, 2013; Csorba et al, 2015; Baumberger et al, 2007). Among all VSRs described, only five structures were solved at atomic resolution such as p19 protein of Tombusivirus (Vargason et al, 2003; Baulcombe \& Molnár, 2004), B2 of Flock House virus (Chao et al, 2005), 2b of Cucumovirus (Chen et al, 2008), p21 produced by Beet Western Yellow virus (Ye et al, 2003) and NS3 of Rice Hoja Blanca Tenuivirus (Yang et al, 2011). Solving 3D protein structure of some VSR proteins unraveled interference mechanisms with the RNAi machinery (Xia et al, 2009; Ye et al, 2003; Vargason et al, 2003; Yang et al, 2011). Despite many improvements during last decades, getting 3D protein structures still represent a challenge, which is especially true for viral proteins because of their intrinsic disordered or flexibility properties (Pushker et al, 2013; Xue et al, 2014). In plant viruses, despite numerous 3D structures of CP assembled in virion (DiMaio et al, 2015; Clare et al, 2015; Hesketh et al, 2015; Wang et al, 2015), just a few 3D structures of non-structural proteins are currently available compared to the high number of publications on viral proteins.

The sobemovirus Rice yellow mottle virus (RYMV) belongs to this plant virus category for which only the CP assembled virion 3D structure has been solved. Revealed in 1966 in East Africa by Bakker (Bakker, 1970), RYMV rapidly spread in rice culture from East to West Africa (Abubakar et al, 2003; Fargette et al, 2004; Traore et al, 2005) with a worrying epidemiological profile, generating crop losses ranging from 20 to $100 \%$ depending on the year and the environmental conditions. RYMV's genome is a positive single-stranded, non-polyadenylated, linear RNA of $4.450 \mathrm{~kb}$ long. The genomic organization is related to the Cocksfoot mottle virus (CfMV), and includes 5 ORFs (Ling et $a l, 2013$; Sõmera et al, 2015). The most emblematic multifunctional protein in RYMV is the P1 protein encoded by ORF1 of the genome, this protein is a small Cysteine-rich protein of $18 \mathrm{kDa}$, which is required for virus movement (Bonneau et al, 1998; Siré et al, 2008), suspected in viral replication (Bonneau et al., 1998), and described as a suppressor of RNA silencing directed against exogenous genes in plant reporter systems (Voinnet et al, 1999; Siré et al, 2008; Lacombe et al, 2010; Fusaro et al, 2012). The P1 protein presents the highest diversity among the other viral proteins with 17,8\% of amino acid sequence divergence (Siré et al, 2008; Sérémé et al, 2014). All functions achieved by P1 play a crucial role during early steps of viral infection, however little is known concerning its mode of action. P1 presents two couples of Cysteine (Cys) organized in Cys- $\mathrm{X}_{2}$-Cys motifs similar to a zinc finger (ZnF) (Gillet et al, 2013) and highly conserved among RYMV P1 diversity (Cys 64- $\mathrm{X}_{2}$-Cys 67 and Cys 92- $\mathrm{X}_{2}$-Cys 95), and remarkably, in the $\mathrm{P} 1$ of sobemovirus genus (Sõmera et al, 2015). Point mutations were introduced on Cys residue of each Cys- $\mathrm{X}_{2}$-Cys motif (Cys 64 and Cys 95), which impaired silencing suppression and cell-to-cell movement in transgenic rice respectively, indicating a central role of Cys residues for P1 functions (Siré et al, 2008). Using a biochemical approach coupled with mass spectrometry, we showed that P1 binds two $\mathrm{Zn}$ atoms in its 
reduced state, whereas its oxidation induced complete $\mathrm{Zn}$ release accompanied by disulfide bonds formation, structural modification and oligomerization (Gillet et al, 2013). This process could be reverted by adding a reducing agent, indicating that $\mathrm{P} 1$ is a $\mathrm{Zn}$ binding protein with redox flexibility and oligomerization properties in vitro, highlighting the importance of Cys residues for P1 behavior. Nevertheless, the molecular organization of $\mathrm{P} 1$ and of its two $\mathrm{Zn}$ binding domains remains unclear and the precise role of $\mathrm{P} 1$ in viral infection widely unknown.

In this paper, we describe the elucidation of the structure and dynamics of the full multifunctional P1 protein from the Rice Yellow Mottle Virus, described both as a movement protein and as a VSR. By combining biochemistry, mass spectrometry and structural biophysics, we have determined the molecular organization of this multifunctional protein, localized two Zinc fingers and put forward flexibility of the C-terminal portion with respect to the $\mathrm{N}$-terminal portion. By mutagenesis approaches directed at residues identified as potential critical sites by the structure analysis, we have identified key areas involved in virus accumulation and movement into the host plant.

\section{Results}

\section{Delineation of P1 zinc binding domains}

In a previous work, we found that $\mathrm{P} 1$ binds two zinc atoms in a reduced environment (Gillet et al, 2013), but the high number of rigorously conserved cysteine (7) and histidine (6) residues in P1 diversity (Appendix Fig S1) prevented the identification of the amino acids involved. To address this question, we designed a series of recombinant P1 regions (Fig 1A, Appendix Supplementary Text, Appendix Fig S2-S3, Appendix Table 1- Table 2) and evaluated their capacity to bind zinc using a 4(2-Pyridylazo) resorcinol (PAR) labeling assays. Figure 1B shows that zinc detected by the PAR probe co-localized with all P1 regions assayed in a SDS-PAGE. Re-sizing [1-100] and [50-157] regions into shorter [50-100] and [102-157] amino acid regions, respectively, allowed us to definitely assign the zinc binding capacity to these two latter central and C-terminal regions of P1 (Fig 1B). Native ESI-MS confirmed the zinc binding at [50-100] and [102-157] amino acid regions (Table 1, Appendix Fig S4$\mathrm{S} 5)$, further termed $\mathrm{ZnF} 1$ and $\mathrm{ZnF} 2$, respectively.

\section{ZnF1 and ZnF2 in P1 exhibit different zinc binding affinity}

Our previous analyses suggested that P1 binds its two zinc atoms with differential affinity (Gillet et al, 2013). To further address this question, we first performed EDTA treatments followed by native ESIMS analyses on the full-length P1 protein and found that treatments up to 400 molar equivalents (eq) of EDTA were sufficient to provoke the release of one zinc atom (Table 1 and Appendix Fig S6A, compare upper and mid panels). This zinc atom could partially reload into P1 after treatment of the EDTA-chelated protein with $100 \mu \mathrm{M}$ ZnOAc (Table 1 and Appendix Fig S6A, lower panel). All 
attempts to provoke the release of the second zinc atom from P1 using higher EDTA concentrations were unsuccessful.

Similar assays were then performed on P1 shorter regions [1-100] and [102-157], the two other proteins P1_50-100 and P1_50-157 being improper for ESI-MS analyses after EDTA treatments. Treatments up to 400 molar equivalents of EDTA applied to the ZnF1-containing P1_1-100 protein failed to release the unique zinc atom present in this shorter P1 protein (Table 1 and Appendix Fig S6B). In order to determine $\mathrm{ZnF} 1$ zinc affinity constant, we first subjected P1_1-100 (40 $\mu \mathrm{M})$ to N,N,N,N-Tetrakis(2-pyridylmethyl)-ethylenediamine) (TPEN), a heavy metal chelator with a Ka constant of $10^{16} \mathrm{M}^{-1}$ (Anderegg et al, 1977) stronger than that of EDTA (Ka EDTA $=10^{14} \mathrm{M}^{-1}$ (Smith \& Martell, 1989). After chelation by TPEN, we could estimate a zinc affinity constant KaZnF1 of $2,15 \times 10^{16} M^{-1}$, using a PAR/PMPS zinc release assay according to (Jakob et al, 2000) (Appendix Fig S7).

Regarding ZnF2, a treatment with 50 eq of EDTA was sufficient to release the zinc atom (Table 1 and Appendix Fig S6C), indicating that the $\mathrm{ZnF} 2$ domain is much less affine for zinc than $\mathrm{ZnF} 1$. Despite several assays, we were unable to determine the zinc affinity constant of $\mathrm{ZnF}$ 2, suggesting that ZnF2 zinc affinity constant could be lower than that of EDTA itself. We additionally observed that the chelated P1_102-157 protein could reload one zinc atom similarly to the full-length P1 protein once treated with $60 \mu \mathrm{M}$ ZnOAc (Table 1 and Appendix Fig S6). This indicates that the zinc atom rapidly released from the full length P1 protein after EDTA treatment and easily reloaded is the one bound to the $\mathrm{ZnF} 2$ domain.

Because oxidizing environments provoke zinc release from P1 and its oligomerization, (Gillet et $a l$, 2013) (Appendix Fig S8A), we also investigated whether the differential zinc-binding affinities of $\mathrm{ZnF} 1$ and $\mathrm{ZnF} 2$ were related to the respective redox sensitivity of [1-100] and [102-157] regions. Using SDS-PAGE under non-reducing conditions, we found that high $\mathrm{H}_{2} \mathrm{O}_{2}$ /protein ratios (80 eq corresponding to $2 \mathrm{mM}$ ) were required to induce the release of zinc atom from the recombinant P1 and P1_[1-100] proteins, respectively, without affecting their mobility and folding (Appendix Fig 8B, left panel). Reversely, lower $\mathrm{H}_{2} \mathrm{O}_{2}$ /protein ratios (10 eq corresponding to $1 \mathrm{mM}$ ) were sufficient to provoke zinc release from the recombinant P1_[102-157] protein, accompanied by a mobility shift due to oligomerization and slight conformational changes observed by CD (Appendix Fig 8C).

Altogether, these results demonstrate that the N-terminal [1-100] region of P1 comprising ZnF1 is the most affine domain to zinc and also the less sensitive to oxidizing environments, both properties conferring strong structure maintenance of this region. They also identify P1 C-terminal [102-157] domain as the most sensitive region to chelation or oxidant molecules and the most amenable to structural flexibility, sustained by the low zinc affinity of $\mathrm{ZnF} 2$.

\section{P1 N- and C-terminal regions exhibit different structural and zinc binding geometries.}

To go further in the structural characterization of $\mathrm{P} 1$, we subjected the protein to crystallography. As 
all attempts to crystallize the whole protein remained unsuccessful, we took advantage of the different soluble recombinant regions of P1 (Fig 1A) for further analyses, of which P1_1-100 for N-terminal region and P1_102-157 for C-terminal region (P1_102-157) were successfully crystallized at a resolution of 1.9 and $2.1 \AA$, respectively (Fig 2). All crystallographic and refinement statistics are given in Table 2.

A remarkable feature of P1_1-100 crystal structure was the formation of a dimer from paired antiparallel monomers (Fig 2A), a property that we confirmed by using an in vivo yeast-two hybrid assay (Appendix Fig S9). Each monomer contains a zinc atom (Fig 2A-B) and consists in a sandwich composed of 6 strands (A-F, Fig 2C-D) and 2 short helices (H1 and H2, Fig 2C-D) at each extremity. The overall sandwich structure itself arises from the duplication of a subdomain containing three strands, the two sub domains (A-C and D-F strands) superimposing with a r.m.s.d. of $1 \AA$ on $\mathrm{C} \alpha$ atoms. Searching for similar folds among known structures with DALI (Holm \& Rosenström, 2010) returned only one significant hit with SCOP fold families (sandwich, 6 strands, 2 sheets), suggesting that P1_1-100 could be documented as a new member of this family. The presence of the zinc finger at the C-terminal extreme side of the sandwich, involving Cys64, Cys67, Cys92 and Cys95 as zinc ligands (Fig 2A-B), validates the identification of a CCCC-type ZnF1 domain at the [50-100] and [1100] regions of P1 by our SDS-PAGE/PAR coupled assays and ESI-MS analyses (Fig 1B, Table 1). The importance of this CCCC-type $\mathrm{ZnF} 1$ in the maintenance of the sandwich fold and P1 solubility was demonstrated by additional SDS-PAGE and ESI-MS experiments on single and double cysteinic and histidinic recombinant mutants (Appendix Supplementary Results and Appendix Table 1 \& 2) of both the entire P1 (Appendix S10 and S11) and its P1_50-100 region (Appendix S12 and S13), this latter region corresponding to the D-F subdomain (Fig 2). According to the crystal structure, both Cys64 and Cys67 belong to a $\beta$ turn between strands D and E, whereas Cys95 is located at the beginning of helix 2 (Fig 2B-C). Hence, $\mathrm{ZnF} 1$ belongs to the treble clef group, albeit not a canonical form as Cys92 does not belong to helix 2 (Krishna et al, 2003; Kaur \& Subramanian, 2016). Another remarkable feature of P1_1-100 is the presence of a helix harboring a lysine (Lys17) completely solvent exposed (Fig 2D). This lysine is highly conserved within P1 diversity and position 17 indeed tolerates only replacement by arginine residues (one sequence among 51 inspected, Appendix Fig S1), suggesting that this residue could be a potential site for interaction with protein or nucleic acid partners. Interestingly, this helix is stabilized by a network of hydrogen bonds between highly conserved polar residues (Thr11, Gln13 and Thr14, Fig 2D and Appendix Fig S1) and by contacts between the hydrophobic Ala15 and Val21 residues, whose lateral chains face a hydrophobic pocket within the sandwich.

Contrary to P1_1-100, the final model of P1_102-157 at the resolution of $2.1 \AA$ was monomeric. This observation is in accordance with the absence of homo-dimerization ability of this P1 region in an Y2H assay (Appendix Fig S9). P1_102-157 crystals revealed an original fold consisting in one $\alpha$ helix (residues 103-126) at the N-terminal region of this domain and a rigid part devoid of any secondary 
structure (residues 127-157, Fig 2E). This rigid part contains three zinc ligands Cys140, His145 and Cys149 whereas the fourth ligand His109 belongs to the N-terminal helix (Fig 2F). The compact structure of this P1 C-terminal region is ensured by the zinc finger folding, as demonstrated by additional SDS-PAGE experiments on cysteinic and histidinic mutants of this 102-157 region (Appendix Supplementary Results, Appendix Fig S12B). EDTA-mediated zinc chelation promoted its unfolding, as shown by its ${ }^{1} \mathrm{H}$ NMR spectrum (Appendix Fig S14). These observations validate the identification of a HCHC-type ZnF2 domain at the [102-157] region of P1, confirming our previous predictions (Gillet et al, 2013). The striking architecture of P1 ZnF2 (3 ligands in a loop and one on a helix, Fig 2F) does not belong to any existing class of Zn finger (Krishna et al, 2003). Searching for similar structures with DALI neither returned significant hits. Thus P1 ZnF2 seems to be a member of a new $\mathrm{ZnF}$ class, not only because of its typology, but also because of its "HCHC" box nature. Another striking feature of this domain is its high number of positively charged residues, most of them with their side chain exposed to solvent (Fig 2E). In particular, the extreme C-terminal part presents a patch of highly conserved solvent-exposed lysine and arginine residues (Arg150 and Lys153) which only tolerates Arg to Lys or Lys to Arg replacement, overlapping with a stretch of aromatic residues (Phe151, Tyr154 and Phe157) which tolerates no or only replacement with aromatic residues (Tyr154 excepted, for which a replacement with a cysteine is also observed in one sequence among the 51 inspected) (Appendix Fig S1).

\section{Deciphering the overall P1 structure by NMR}

To unravel the structure of the full-length P1 protein, we led a parallel NMR investigation on the full length P1 and its two sub-regions, P1_1-100 and P1_102-57. Backbone ${ }^{15} \mathrm{~N}$ and ${ }^{1} \mathrm{H}$ chemical shifts are exquisite reporters of protein conformation. The perfect superimposition of cross peaks between the ${ }^{1} \mathrm{H}-{ }^{15} \mathrm{~N}$ HSQC spectrum of full length P1 and that of its [1-100] and [102-157] regions (Fig 3A and 3B, respectively) established that the structure of the individual regions solved by X-Ray (Fig $2 \mathrm{C}$ and $2 \mathrm{E}$ ) is conserved in the whole protein. It also indicates that the interaction between both $\mathrm{N}$-terminal and $\mathrm{C}$ terminal domains of $\mathrm{P} 1$, if any, was minimal which is supported by the absence of interaction between P1_1-100 and P1_102-157 in a yeast two-hybrid assay (Appendix Fig S9). The titration of ${ }^{15} \mathrm{~N}$ labelled C-terminal domain by the non-labeled P_1-100 (Fig 3C) neither showed evidence of interaction. Furthermore, analysis of the chemical shifts $\left(\mathrm{H} \alpha,{ }^{13} \mathrm{C} \alpha,{ }^{13} \mathrm{C} \beta, \mathrm{CO}\right)$ by TALOS (Shen \& Bax, 2013) (Appendix Table 3) and of the ${ }^{1} \mathrm{H}-{ }^{1} \mathrm{H}$ NOEs (Fig 3D) in the linker region established that the C- and N-terminal helices seen in X-Ray structures of P1_1-100 and P1_102-157 (Ala94 to Glu96 and Glu104 to Glu126, respectively) were extending to the entire linker region between both domains in the full-length protein. This folding of the linker into a helix was retrieved in structure calculations, where the linker was only restrained by ${ }^{1} \mathrm{H}-{ }^{1} \mathrm{H}$ NOEs and TALOS-derived dihedral angles. In these calculations of full P1 structure, the $\mathrm{N}$ - and $\mathrm{C}$-terminal domains were fixed to the $\mathrm{X}$-Ray structures, with their mutual orientation restrained by residual dipolar coupling constants (RDC) (Fig 4A). The 
helix linking both domains is however not entirely rigid. Both RDC measurements (Fig 3E) and ${ }^{15} \mathrm{~N}$ relaxation data (Fig 3F and Appendix Table 4) established that P1_1-100 and P1_102-157 domains have some degree of flexibility with respect to each other. RDC measurements enabled the derivation of a global order parameter of 0.78 of $\mathrm{ZnF} 2$ relatively to $\mathrm{ZnF1}$ (Tolman et al, 2001). This value corresponds to a motion amplitude of \pm 30 degrees, following the formalism of Tolman under the assumption of an axially symmetric "wobble-in-a-cone" movement (Tolman et al, 2001).

In the NMR-derived structure, the whole P1 protein presents a surface with an original polarized profile (Fig 4B). On one face, the central region harbors a large negatively charged patch, formed by conserved Glu5, Asp37, Asp43, Asp94, Glu96, Glu108, Asp141, and Glu144. The other side harbors two extremal positively charged poles at the $\mathrm{N}$ - and C-terminal parts, which overlap with the potential interaction motifs described above. Indeed, the first positive pole is constituted in $\mathrm{ZnF} 1$ by $\mathrm{Arg}$, Lys17 and Lys78 side chains forming a hydrophobic and positively charged cleft. The second positive pole is constituted in $\mathrm{ZnF} 2$ by the C-terminal extremity (Arg150, Lys153), which alternates with aromatic residues (Fig 2E).

\section{Oligomeric structure of P1}

The superimposition of two [1-100] monomers in the crystal of P1_1-100 (Fig 2A) and yeast-two hybrid assays (Appendix Fig S9) indicated that P1 forms a dimer through its N-terminal region. In the asymetric unit (Fig 4C and Appendix Fig S15A, upper scheme), the dimeric interface involves five hydrogen bonds between residues Met1 and Glu75, Gln34 and Glu75, Tyr71 and Tyr72, together with 10 hydrophobic contacts involving residues Gln34, Gln76, Trp29, Trp31, Glu75, Ser33, Ser74, Trp57, Thr35, Thr73. The dimer interface is further strengthened by four salt bonds between Met1 and Glu75. The overall interface surface was estimated at $506 \AA^{2}$ (Appendix Fig S15B and Appendix Table 5), hence $8.4 \%$ of the total surface of one monomer $\left(6019 \AA^{2}\right)$, classifying this dimeric form as labile. Accordingly, ESI-MS analyses detected only a faint proportion of P1 dimers for full length P1 (Gillet et al, 2013). The overall $\mathrm{P} 1$ crystal packing also revealed a second potential dimerization interface between P1_1-100 monomers (Fig 4D and Appendix S15A, lower scheme). This crystallographic interface, estimated at $574 \AA^{2}$, involves six hydrogen bonds linking His87 with Asp89, Thr68 with Tyr72, and Ser74 with Thr68 of each monomer, but also twenty hydrophobic contacts implicating Pro85, His70, Tyr72, Thr68, Gln66, Ser79, and Trp57 in each monomer. This interface is also strengthened by Ser59-Ala63 and Ser61-Ser61 saline bonds via the bridging of water molecules. Analysis of the crystal data indicated that P1_1-100 could undergo into a tetrameric structure stabilized by the coordination of a fifth zinc atom by the 4 His 70 residues belonging to the $4 \mathrm{P} 1 \mathrm{~N}$ terminal regions (Fig 4E). Such a tetrameric structure would involve salt bridges and water molecules between His70 and the latter zinc atom. To challenge such possibility, we subjected the full-length P1 and its truncated form P1_1-100 to size-exclusion chromatography coupled with multi-angle laser light scattering (SEC-MALS). At low salt concentrations, both the full length and its N-terminal region 
[1-100] eluted as monomers in a zinc-free elution buffer and as a dimer in a zinc-containing elution buffer (Fig 4F). No trace of higher molecular weight proteins could be detected. On the other hand, NMR relaxation studies performed at high salt concentration were in favor of a monomer (Appendix Table 4). No relaxation data could be recorded at low salt concentration, as the protein was unstable in the protein concentration range needed $(200 \mu \mathrm{M})$.

We next built the corresponding models of homodimeric and tetrameric P1 models based on the NMR-derived full-length P1 structure. No steric clash was observed. Interestingly, the dimeric interface (asymmetric unit) mixes the characteristics of the electrostatic surface of both sides of P1 monomeric form, in particular the presence of the central large negative patch and of the extremal positive poles in $\mathrm{ZnF} 1$ and $\mathrm{Znf2}$ (Fig 4G). By contrast, a doubled negative central patch is observed in P1 built from the crystallographic dimer, interrupted by a positive spot constituted by the two side chains of the conserved Arg3 residue of each protomer. Consequently, the tetrameric form of P1 maintains the presence of the large central negative patch and of the extremal positive poles in $\mathrm{ZnF} 1$ and $\mathrm{ZnF} 2$, but the access to the positive and aromatic pole of ZnF2 (Arg150, Phe151, Lys153, Tyr154, Phe157) is hampered (Fig 4G).

\section{Oligomerization of P1 N-terminal region is essential for viral spread in rice}

To evaluate the biological importance of P1 structural features and oligomerization properties in RYMV infectivity, we took advantage of FL5, a RYMV DNA clone allowing the production of infectious viral RNAs that can be directly inoculated in rice plantlets (Brugidou et al, 1995). P1 residues selected for their potential key position within P1 structure were therefore mutated in the P1 open reading frame (ORF) within the FL5 sequence and rice plants infected by viral RNAs carrying mutations were recorded for RYMV fitness and infectivity. We first focused on the short solventexposed [Lys17-Val21] helix at the N-extremal part of the P1 sandwich that is potentially accessible for ligand binding and sandwich structure maintenance (Fig 2D). By comparison with plants inoculated with infectious FL5 RNAs (Fig 5) and with a non-infectious FL5 $\triangle \mathrm{P} 1$ clone impaired in P1 translation (Fig 5, Appendix Supplementary Results and Appendix Fig S16), we found that inoculating plants with FL5 RNAs depleted of the P1 DNA region encoding residues 12 to 21 containing this protuding helix (FL5-P1 ${ }^{\Delta 12-21}$, Fig 5A) did not provoke viral infection. Only very few amounts of viral particles were detected as revealed by DAS-ELISA, and inoculated plants showed similar height (Fig $5 \mathrm{~B}$ ) and green healthy leaves (Fig 5C) to that plants inoculated with the non-infectious FL5 $\Delta \mathrm{P} 1$. Interestingly, we failed to produce a P1 recombinant protein depleted of this helix in E. coli cells, suggesting that the short N-terminal helix in P1 has a great importance for its folding. To go further, we used plant protoplasts as a reporter system to evaluate P1 behavior in vivo, and found that both $\mathrm{P}^{\Delta 12-21}$-EGFP and EGFP-P1 $1^{\Delta 12-21}$ fluorescent fusion proteins had low fluorescence capacities and a tendency to aggregate in the cytosol, while the wild-type P1-EGFP and EGFP-P1 fusion proteins both locate in the cytosol and in the nucleus (Appendix Fig S17). Altogether, these experiments indicate 
that the short helix at the $\mathrm{N}$-terminal region of $\mathrm{P} 1$ is essential at least for $\mathrm{P} 1$ folding, most probably by ensuring the SCOP fold of the sandwich region of P1 at its N-terminal region.

We also evaluated the role of tryptophan residues present in P1 N-terminal region by creating Trp-to-Ala or Trp-to-Ser replacements in the P1 sequence (Appendix Table 1). Trp residues (4 in P1) were selected firstly because they all locate in this region that undergoes oligomerization according to our data. Trp29, Trp31 and Trp57 have their side chain exposed to solvent and accessible to ligand binding, and participate to hydrophobic contacts in the asymmetric interface (Fig 3D, Appendix Fig S15 \& S18A). Trp57 additionally participates in the crystallographic interface, while Trp36, which is buried in a hydrophobic core of ZnF1 (Appendix Fig S18B), locates on the same $\beta$-strand as Trp29 and Trp31. All these Trp are strictly conserved among P1 diversity within the RYMV sobemovirus gender (Sérémé et al, 2014), which suggests their importance for P1 functions. Rice plants were therefore infected by viral genomic RNAs expressing Trp-mutated P1s and recorded for RYMV fitness and infectivity. By comparison with infection levels induced by the original FL5 RNA, we found that viral RNAs expressing either $\mathrm{P} 1^{\mathrm{W} 29 \mathrm{~A}}$ or $\mathrm{P} 1^{\mathrm{W} 31 \mathrm{~A}}$ proteins only induced a faint production of RYMV particles in infected leaves (Fig 5A), with a slight growth decrease only (Fig 5B), and with RYMV symptoms limited to very few yellowing areas, mostly in plants inoculated with FL5- P1 ${ }^{\text {w29A }}$ RNAs (Fig 5C). This FL5 variant appeared as the sole infectious clone able to provoke a moderate accumulation of viral particles in systemic leaves (Fig 5A-C). Mutating Trp36 in P1 within FL5 (FL5$\mathrm{P} 1^{\mathrm{W} 36 \mathrm{~A}}$, Fig 5A) provoked a more important defect in RYMV particle accumulation in inoculated leaves, abolishing RYMV systemic movement to non-infected tissues (Fig 5A). Reversely, mutating Trp57 had minor effects on RYMV fitness, as plants showed similar symptom manifestation in rice plants to that of the wild-type FL5 infectious clone, especially in systemic tissues (Fig 5A) where it induced strong yellowing (Fig 5C). This suggests that Trp57 plays a minor role during RYMV infection. The further analysis of the related recombinant Trp29, 31 and 36 mutant proteins in E. coli (Appendix Tables 1) indicated that recombinant $\mathrm{P} 1^{\mathrm{W} 29 \mathrm{~A}}$ and $\mathrm{P} 1^{\mathrm{W} 31 \mathrm{~A}}$ proteins were still soluble in $E$. coli (Appendix Fig S19, Appendix Table 2), the remaining insoluble fraction being probably due to protein overproduction), while W36A mutation led to strong protein aggregation (Appendix Fig S19). We also observed that the W36A mutation provoked partial aggregation of both EGFP-P $1^{\mathrm{W} 36 \mathrm{~A}}$ and P1

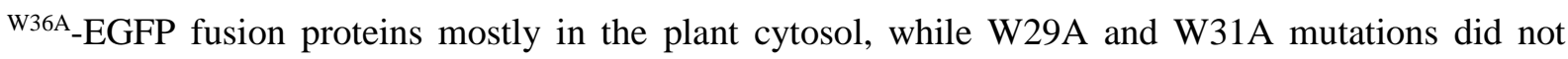
affect P1 sub cellular patterns (Appendix Fig S17). These results indicate that Trp residues at positions 29, 31 and 36 are important for RYMV infectivity, either for their role in P1 oligomerization (Trp29 and Trp31) or in the maintenance of $\mathrm{P} 1$ structure in a close environment of the $\mathrm{ZnF} 1$ region (Trp36).

\section{C-terminal Zinc finger structure is required for $\mathrm{P} 1$ viral functions.}

According to our structural data, $\mathrm{ZnF} 2$ may ensure a central function in the folding of $\mathrm{P} 1 \mathrm{C}$-terminal region. This region is also more sensitive to oxidation and less affine to zinc. We thus addressed the question of the biological role of ZnF2 during rice infection by RYMV RNAs through the use of FL5 
RNAs $\mathrm{C} 140 \mathrm{H}$ and $\mathrm{C} 149 \mathrm{H}$ mutations generating artificial $\mathrm{HHHC}$ and $\mathrm{HCHH} \mathrm{ZnF} 2$. Such mutations allow assessing redox behavior while keeping zinc coordination safe (Negi et al, 2004), and like C140S and C149S mutations, they do not alter P1 pattern in plants cells (Appendix Fig S17). Fig 6 shows that both FL5 infectious clones carrying $\mathrm{C} 140 \mathrm{H}$ or $\mathrm{C} 149 \mathrm{H}$ mutations were noninfectious in rice plants, as shown by the almost total lack of viral particles in inoculated and systemic tissues (Fig 6A), by the unaffected growth of the plants and their healthy leaf phenotypes (Fig 6B-C). This indicates that integrity of Cys140 and Cys149 is mandatory for RYMV infectivity, probably in maintaining ZnF2 liability and/or redox-sensitive flexibility.

We also challenged the importance of the strictly conserved C119 and the sole free Cysteine residue in P1 (Gillet et al., 2013) for the virus by creating a Cys119Ser mutation in FL5 to impair potential redox modifications of this residue. This mutation does not modify P1 solubility in vitro and in plant cells (Appendix Fig S10 and S17), or its zinc binding properties (Appendix Fig S10). Indeed, we found that infecting rice with FL5-P1 ${ }^{\mathrm{C} 119 \mathrm{~S}}$ did not provoke major differences in viral fitness, as this clone remained highly infectious in rice for all traits analyzed (Fig 6A-D). Cys119 residue is thus dispensable for P1 functions despite its structural accessibility.

Another P1 feature of interest is its highly hydrophobic and strongly conserved KYNLF sequence (NLF motif being strictly conserved in all P1s) ending the C-terminal part P1 (Appendix Fig S1). According to P1 structure (Fig 2 \& 4), this region is largely solvent exposed and may be accessible for ligand binding. Deleting this KYNLF stretch in P1 fused to EGFP did not alter P1 localization in rice cells (Appendix Fig S17), and a ${ }^{1 D} \mathrm{NMR}$ analysis of a corresponding recombinant $\mathrm{P}^{\Delta 153-157}$ suggested that the KYNLF deletion does not generate protein instability or misfolding (Appendix Fig S20). But strikingly, the same KYNLF deletion in P1 ORF within FL5 strongly delayed the infectious capacities of the corresponding FL5-P1 ${ }^{\Delta 153-157}$ viral RNAs, viral particles being detectable only from the $5^{\text {th }}$ week in both inoculated and systemic tissues (Fig 6A), with limited symptoms in term of plant growth retardation and yellowing (Fig 6B-C). This demonstrates that the five external amino acids at $\mathrm{C}$-terminal end of P1are essential for virus infectivity.

\section{Discussion}

Plant viruses count among the most damaging pathogens to plant growth, affecting not only plant fitness and crop yields, but also food quality. Determining the crystal structure of viral components mandatory for plant infection and spread in host tissues is a key step for a better understanding of the mechanisms underlying viral functions that in turn allows the development of adapted strategies for a better agronomy. Viral RNA silencing suppressors that specifically counteract the plant anti-viral RNAi pathway (Ding \& Voinnet, 2007) are therefore particularly good candidates for which crystal structures are requested.

Here, we report the first complete 3D structure of an essential VSR protein from a member of the sobemovirus family, which infects the monocotyledonous model plant Oryzae sativa. To date, only 
few VSRs encoded by plant viruses have been crystallized (Baulcombe \& Molnár, 2004; Ye et al, 2003; Chen et al, 2008; Yang et al, 2011) and of these, only one comes from a rice virus (Yang et al, 2011). Thus, the P1 structure described here contributes to fulfill an important gap of knowledge regarding VSRs. We show that P1 contains two sub-domains, harboring each a zinc finger but with completely different architectures. The N-terminal sub-domain folds as a compact sandwich composed by two repeats of $3 \beta$-sheets, essentially maintained by a 4-Cys Zinc finger at its C-terminal extremity and by a short prominent helix at its N-terminal extremity. The C-terminal subdomain of P1 is composed by a long $\alpha$-helix and a rigid part devoid of secondary structure, the latter elements being stabilized together by a second $\mathrm{ZnF}$ of a new type, namely His-Cys-His-Cys. The NMR analysis revealed that the individual structures of each sub-domain solved by X-Ray crystallography were retrieved in the whole protein, and behaved as independent and flexible structural units in this context. Other VSR proteins were previously shown to be organized in modules, including $\mathrm{ZnF}$ recognized domains pointing to their involvement in diverse viral functions (López et al, 2000; Dong et al, 2003; Van Wezel et al, 2003; Trinks et al, 2005; Yang et al, 2007; Yambao et al, 2008; Valli et al, 2008; Chiba et al, 2013; Lukhovitskaya et al, 2013; Kenesi et al, 2017; Fujita et al, 2018). To our knowledge, we here report the first 3D structure revealing $\mathrm{ZnF}$ features within a plant VSR protein, with very few similarities with other proteins in the databases.

P1 protein is essential for RYMV systemic spread in rice tissues (Bonneau et al, 1998; Siré et al, 2008) and also plays an important role in viral replication despite being not strictly essential in this early step of RYMV infection (Bonneau et al, 1998; Nummert et al, 2017). Indeed, a mutation of P1 translation initiation codon rendering P1 undetectable in infected rice tissues almost abolished RYMV particles accumulation in infected and systemic leaves. Mutation on Cys64 and Cys95 had also been reported to have a negative impact on RYMV fitness (Siré et al, 2008). Our present work now brings a better understanding on how punctual mutations introduced at $\mathrm{ZnF} 1$ and $\mathrm{ZnF} 2$ on Cys residues impair viral infection, either by decreasing protein solubility and provoking protein misfolding and aggregation (Cys64S, Cys95S, Appendix fig S10 to S14 and S17), or by potentially decreasing P1 redox sensitivity, structural flexibility and/or ligand binding capacities $(\mathrm{C} 140 \mathrm{H}, \mathrm{C} 149 \mathrm{H}$, Fig 6 and Appendix Fig S17). Based on those results, the use of Cys mutants in different approaches revealed the necessity to conserve $\mathrm{ZnF} 1$ and $\mathrm{ZnF} 2$ integrity and structure for P1 functions. Similar results were observed for other viral $\mathrm{ZnF}$ proteins, e.g. is the replacement of His by Cys or $\mathrm{ZnF}$ depletion in NCp7 protein that resulted in a complete loss of HIV infectivity, as well as loss of interactions with viral protein partners such as Vpr and host partners RPL7 (Demene et al, 1994; de Rocquigny et al, 1997; Mekdad et al, 2016). Another example is illustrated by AC2 or its homologous C2 protein from mung bean yellow mosaic virus and tomato yellow leaf curl virus respectively. Cys mutations involved in their $\mathrm{ZnF}$ decreased or totally abolished $\mathrm{Zn}$ affinity, VSR activity and transactivation properties (Dong et al, 2003; Trinks et al, 2005; van Wezel et al, 2002). However, the P1 protein presents the unusual particularity to possess two zinc-fingers of different types, an atypical feature never reported before to 
our knowledge. Of note, $\mathrm{P} 1 \mathrm{C}$-terminal $\mathrm{ZnF} 2$ is at least hundred times more sensitive to $\mathrm{Zn}$ chelation and two times more sensitive to oxidation than $\mathrm{ZnF} 1$, indicating its higher chemical reactivity. These results are in accordance with their integration in $\mathrm{P} 1$ overall structure: $\mathrm{ZnF} 1$ functions as a closing cap of a compact beta-sheet sandwich, with limited access to the zinc atom, whereas $\mathrm{ZnF} 2$ bridges together structural elements that have minimal interacting secondary structures. Hence, zinc chelating and/or oxidation is easier in $\mathrm{ZnF}$ 2, the $\mathrm{Zn}$-release leading to unfolding of this domain. From all these data, we hypothesize that ZnF2 controls P1 redox flexibility. Different protein models have already been characterized for redox dependent $\mathrm{Zn}$ binding/release and subsequent 3D structure modifications that control in vivo functions. The bacterial Hsp33 possesses one $\mathrm{ZnF}$ composed of 4 Cys residues that undergoes disulfide bond formation and subsequent $\mathrm{Zn}$ release upon oxidative conditions (Barbirz et $a l, 2000$ ), provoking the structural unfolding of Hsp33 C-terminal domain and the dimerization of the protein required to activate its chaperone function (Barbirz et al, 2000; Graumann et al, 2001; Winter et al, 2008; Ilbert et al, 2007). RsrA protein exemplifies a second mechanism of $\mathrm{ZnF}$ redox regulation. $\mathrm{RsrA}$ binds one $\mathrm{Zn}$ atom in its reduced state, this conformation being responsible for sigma factor sequestration. Oxidative stresses induce $\mathrm{Zn}$ release that accelerates sigma factor dissociation from RsrA, a process accompanied by disulfide bond formation and conformational changes by burying hydrophobic core necessary for sigma factor interaction. This overall process leads to RNA Pol activation through interaction with sigma factor, then RNA Pol-sigma factor complexes triggered transcription of redox balance genes (Paget et al, 2001; Li et al, 2003; Rajasekar et al, 2016). In P1 protein, the loss of $\mathrm{ZnF} 2$ structure upon zinc chelation/and or oxidation could serve as a new regulation level for the mutual orientation of the interaction motifs of $\mathrm{ZnF} 1$ and $\mathrm{ZnF} 2$ described in this study. We hypothesize that $\mathrm{P} 1$, in order to orchestrate such different functions during viral infection, has to fine-tune its structural conformation to modulate interactions with different partners.

Indeed, each subdomain was found to harbor a potential interaction motif with nucleic acids or proteins. This spot was constituted by a solvent-exposed helix for the N-terminal part, and a stretch of basic residues overlapping with aromatic residues for the C-terminal part. The importance of these motifs is highlighted by the fact that deletion of the solvent exposed helix at N-terminal extremity $\left(\mathrm{P} 1^{\Delta 12-21}\right)$ or of the five external amino acids at $\mathrm{C}$-terminal end $\left(\mathrm{P} 1^{\Delta 153-157}\right)$ leads to a complete loss of virion infectivity in planta (Fig 6A). We note that the relative flexibility of both sub-domains therefore offers a great potential in differently aligning these interaction motifs, multiplying the different regulation levels. Unexpectedly, an additional level of regulation is provided by the oligomerization properties of P1. Our structural data show that P1_1-100 crystal structure presents two potential dimeric interfaces but surfaces and binding energy calculated suggest that those dimers are labile (Chen et al, 2013). Nevertheless, dimerization was confirmed in vivo by yeast two-hybrid for P1_1100 and in vitro by SEC-MALLS experiments for P1_1-100 and P1 full length. Moreover, mutations of Trp29 and Trp31, which are involved in dimerization interface (asymmetric unit), negatively impact systemic spreading of the virus with a strong delay or a complete loss of virus accumulation in 
systemic leaves respectively. This result highlighted the biological relevance of P1 dimeric interface observed in the asymmetric unit. Similarly to P1, other known VSR structures were obtained in dimeric conformation such as p19, NS10, B2 and 2b (Vargason et al, 2003; Ye et al, 2003; Baulcombe \& Molnár, 2004; Chao et al, 2005; Chen et al, 2008; Yang et al, 2011) or octameric form for p21 (Ye $\&$ Patel, 2005). The multimeric state of those proteins were always associated with dsRNA binding activity required for VSR functions, especially in p19 structure presenting a WxxW motif required for siRNA binding (Vargason et al, 2003; Ye et al, 2003). This motif is also found in the Rice Dwarf Phytoreovirus Pns10 protein, and mutation of this motif alters its VSR activity (Ren et al, 2010). In $\mathrm{P} 1$, Trp29 and Trp31 form a related motif $\mathrm{W}_{29} \mathrm{XW}_{31}$, however $\mathrm{P} 1$ seems to behave differently compare to other VSRs with known structures, as all attempt to observe RNA binding activities were unsuccessful in our experimental conditions. Therefore, we hypothesize that the mechanism of interference with $21 \mathrm{nts}$ and 24 nts siRNA previously described seems to occur in an RNA binding independent manner not yet understood. Moreover we cannot exclude that Trp29 and Trp31 residues forming a WxW motif are also involved in cellular partner's recruitment necessary for viral systemic infection. Taking into account that the phenotype of RYMV carrying Trp29 or Trp31 mutations relies on systemic movement reduction or deficiency, we hypothesize that dimerization properties and/or partners recruitment involving this motif play a crucial role in viral movement, which might be correlated or uncoupled with VSR properties and viral replication. We also hypothesize that those two mutants might be used to decipher the molecular mechanism of P1 involved in virus movement and/or RNAi evasion. This question has to be further addressed to fully decipher P1 functions. Regarding the C-terminal region of $\mathrm{P} 1$, the extreme C-terminal part presents a patch of highly conserved solventexposed lysine and arginine residues (Arg150 and Lys153) which only tolerates Arg to Lys or Lys to Arg replacement with the other positively charged residue, overlapping with a stretch of aromatic residues (Phe151, Tyr154 and Phe157) which tolerates no or only replacement with aromatic residues (Tyr154 excepted, for which a replacement with a cysteine is also observed in one sequence among the 51 inspected) (Appendix Fig S1). This region may constitute potential anchoring sites for interaction with nucleic acids and hydrophobic ligands, respectively.

On the other hand, some VSRs such as p38 act in homodimeric or higher multimeric forms to mimic GW repeated motifs involved in Ago1 interactions (Azevedo et al, 2010; El-Shami et al, 2007; Till et al, 2007). Regarding P1 organization, Trp57 is involved in P1 dimeric interface in the crystallographic unit and also forming with Gly56 a potential GW motif. This GW motif might form a GW repeat through P1 dimerization for interacting with Ago proteins. However, we could not obtain experimental evidence for the biological relevance of the GW motif or of the dimeric interface observed in the crystallographic unit, as the mutation of Trp57 did not alter the infectivity profile, a feature that is in line with its low conservation among all P1 isolates (Sérémé et al, 2014 and Appendix figure S1). Punctual mutations in this second potential dimeric interface have to be further investigated. 
Altogether our results lead to a better understanding of P1, a key protein for the RYMV virus, and a unique protein in the database with original features. They notably point out to the multiple levels of regulation of its structure, i.e. flexibility, oxidation and oligomerization and their impact on its function during the viral cycle. Future identification of P1 targets in rice will bring key information on the mechanisms by which P1 interferes with plant anti-viral functions, and assist the design of appropriate strategies to counteract RYMV. Recently, putative 22 nts miRNAs encoded by the genome of $O$. sativa that can potentially target the RYMV genome have been identified using a consensus of four algorithms (Jabbar et al, 2019). Whether such sRNAs could be potential P1 targets for counteracting plant antiviral defenses remains to be evaluated. We have also initiated a deep search of rice proteins as potential P1 interactors. Our work opens huge perspectives towards the understanding on how P1 structural properties sustain P1 sequence diversity among the numerous RYMV isolates identified so far in the African continent and neighboring islands (Rakotomalala et al, 2019) and much beyond among the sobemovirus gender.

\section{Materials and methods}

\section{Plant culture and analyses}

The rice Oryza sativa, cultivar Indica, Var. IR64 was selected for its high sensitivity to the RYMV (Ndjiondjop et al, 1999). Rice plants were grown in confined greenhouse under $12 \mathrm{~h}$ light/12 h dark at $28^{\circ} \mathrm{C}$ and at a relative humidity of $75 \%$, and were watered daily. For rice infection assays, two weekold rice plants (three-leaf stage) were used and cultivated after infection as described above. Inoculations of viral RNAs were performed after in vitro RNA transcription according to (Brugidou et $a l, 1995)$ and are described in details in the Appendix Materials and methods section. Both inoculated and systemic leaves were collected at different times post-infection (from 7 to $28 \mathrm{dpi}$ ) and stored in liquid N2 until use. Protoplasts from 15-day old etiolated rice leaves were prepared according to Chen et al (2009) and transfected according to Zhang et al (2011). All experiments related to confocal microscopy are described in the Appendix Materials and methods.

\section{Constructs}

All constructs expressing P1 and primers used in this study are listed in the Appendix Table 1. For cloning by restriction/ligation, DNA was amplified using the Phusion High-Fidelity enzyme (Finnzymes) and restriction site-containing primers. DNAs were subsequently cloned into destination vectors after digestion by corresponding restriction enzymes (New England Biolabs) and ligation with T4 DNA ligase (Promega). Mutations required for domain excision and/or punctual changes within P1 nucleotidic sequence were introduced in the P1 open reading frame using the QuikChange ${ }^{\circledR}$ II XL Site-Directed mutagenesis kit (Agilent-Stratagene) and related primers (Appendix Table 1). All constructs and mutations created for this study were systematically checked by sequencing on both strands. 


\section{Production and purification of recombinant proteins}

For the production of P1 recombinant proteins, a full-length P1 nucleotide sequence originated from the RYMV Tz3 isolate was already cloned in a pET3b vector (Novagen) between NdeI and BamHI restriction sites to produce the $\mathrm{P} 1$ referent protein (Gillet et al, 2013). Additional truncated P1 proteins (P1_1-100, P1_50-100, P1_50-157 and P1_102-157, amino acid numbering) were generated similarly in the $\mathrm{pET} 3 \mathrm{~b}$ vector. These four constructs were used to generate $\mathrm{pET} 3 \mathrm{~b}$ collections of mutant P1 coding sequences by site-directed mutagenesis, including the pET3b. P1 $1^{\Delta 153-157}$ construct carrying an early stop codon in place of Lys153 (Appendix Table 1).

All recombinant proteins were produced in the E. coli strain BL21-DE3 cells (Novagen) by induction with $0.4 \mathrm{mM}$ IPTG at an $\mathrm{OD}_{600}$ of 0.6 and purified according to (Gillet et al, 2013) with modifications depend on P1 mutants (Appendix Table 2). Protein concentrations were determined by measuring absorbance at $280 \mathrm{~nm}$ using the calculated value of extinction coefficient for each different P1 variant with a Nanodrop spectrophotometer (ThermoScientific).

\section{Far-UV circular dichroism spectroscopy}

CD spectroscopy analyses of reduced or oxidized P1 (12 $\mu \mathrm{M})$ and its sub regions $(25 \mu \mathrm{M})$ were as described for the wild type P1 protein (Gillet et al, 2013). For all experiments, molar ellipticity was calculated as described by Kelly and co-workers (Kelly et al, 2005) on an average of three independent measurements.

\section{SDS-PAGE sample preparation and analyses}

For bacterial fraction analyses, cells were collected by centrifugation in a buffer containing $50 \mathrm{mM}$ Tris-HCl $\mathrm{pH} \mathrm{8,2} \mathrm{mM}$ DTT, then sonicated and separated into insoluble and soluble fractions. Extraction of insoluble protein fraction were performed using Tris- $\mathrm{HCl} 50 \mathrm{mM} \mathrm{pH} 8$ urea $6 \mathrm{M}$ under shaking conditions until insoluble pellets are fully resuspended $(\approx 30 \mathrm{~min})$, then bacterial debris remaining insoluble are eliminated by centrifugation. Renaturation of insoluble proteins were performed by dialysis overnight at $4{ }^{\circ} \mathrm{C}$ under gentle shaking in Tris- $\mathrm{HCl} 50 \mathrm{mM}$ pH8. Protein samples were treated with Laemmli buffer $(40 \mathrm{mM}$ Tris- $\mathrm{HCl}, \mathrm{pH}$ 6.8, $1 \%$ SDS, $50 \mathrm{mM}$ DTT, $7.5 \%$ glycerol, and $0.003 \%$ bromophenol blue) and analyzed by SDS-PAGE in denaturing conditions using $15 \%$ to $18 \%$ acrylamide gels (37.5:1 ratio acrylamide:bis-acrylamide, 40\%) depending on P1 mutants. Purification of P1 mutants from bacterial extracts was performed according to (Gillet et al, 2013). Purified P1 protein $(25 \mu \mathrm{M})$ and its derived truncations $(50 \mu \mathrm{M})$ were analyzed similarly or in nonreducing conditions without DTT according to (Gillet et al, 2013). Redox treatments by different concentrations of $\mathrm{H}_{2} \mathrm{O}_{2}$ or DTT were applied to purified proteins prior to SDS-PAGE analyses either at $20{ }^{\circ} \mathrm{C}$ for $45 \mathrm{~min}$ and in different buffers depending on the experiment (see figure legends). 
On-gel zinc detection in proteins after SDS-PAGE was performed prior to Coomassie blue staining using the zinc-complexing probe PAR (4-(2-Pyridylazo)resorcinol, Fluka) (Lee \& Helmann, 2006).

Immunoblotting was performed after protein transfer onto Hybond-P membranes (GE Healthcare, RPN303F). After blocking membrane nonspecific binding sites in TBS (20 mM Tris, 75 $\mathrm{mM} \mathrm{NaCl}$, and $2.5 \mathrm{mM} \mathrm{MgCl}_{2}, \mathrm{pH} 7.6,5 \%$ milk powder), proteins were subjected to primary antibody recognition using either a purified anti-P1 antibody (1:1000 dilution) raised in rabbit, or an anti-GFP antibody (ThermoFisher). A peroxidase-coupled secondary antibody (anti-rabbit IgG; Immunopure Pierce) was used at a dilution of 1:20000 for primary antibody recognition. The presence of P1 proteins was revealed using the ECL Plus Western Blotting Detection System (GE Healthcare).

\section{Determination of P1_1-100 zinc binding constant}

The affinity of different regions of P1 for zinc ions was determined according to (Jakob et al, 2000) with slight modifications. Purified P1_1-100 $(40 \mu \mathrm{M})$ was first reconstituted after treatment by $2 \mathrm{mM}$ DTT and $300 \mu \mathrm{M}$ ZnSO4, then DTT and unbound zinc were removed using PD10 gel filtration columns (GE Heathlcare) equilibrated with a $40 \mathrm{mM}$ HEPES-KOH, pH 7.5 buffer. Equilibrium between P1_1-100 and zinc was further determined by treating P1_1-100 overnight with increasing concentrations (37 $\mu \mathrm{M}$ to $5 \mathrm{mM}$ ) of the $\mathrm{Zn}$ chelator TPEN ( $N, N, N^{\prime}, N^{\prime}$-tetrakis(2-pyridylmethyl)ethylenediamine) at room temperature in a $50 \mathrm{mM}$ HEPES-KOH buffer ( $\mathrm{pH} 7.5)$ supplemented with $1 \mathrm{mM}$ DTT. TPEN complexed with $\mathrm{Zn}$, free TPEN and free $\mathrm{Zn}$ were further removed by gel filtration on PD MidiTrap G-10 (GE Healthcare) equilibrated with $40 \mathrm{mM}$ of the metal-free HEPES$\mathrm{KOH}$, pH 7.5 buffer. To determine the amount of $\mathrm{Zn}$ still bounded to proteins, we performed a PAR/PMPS assay as follows: $80 \mu \mathrm{l}$ of PAR probe were added to $720 \mu 1$ of protein to a final concentration of $100 \mu \mathrm{M}$. Then we used $1 \mathrm{mM}$ PMPS ( $p$-hydroxymercuriphenylsulfonic acid) which forms mercaptide bond with Cys residues and thus induces the release of the remaining $\mathrm{Zn}$ still bound to protein. $\mathrm{Zn}$ released from $\mathrm{P} 1$ directly reacts with PAR probe to form $\mathrm{Zn}(\mathrm{PAR})_{2}$ complexes colored in far red. We used spectrophotometry absorbance analyses at $\mathrm{A}_{500 \mathrm{~mm}}$ and the GraphPad Prism ${ }^{\mathrm{R}}$ software for non-linear regression and graphic representation to determine the amount of $\mathrm{Zn}$ released by PMPS addition. Values from two independent experiments were used for non-linear regression. We used the following equation for $\mathrm{Zn}$ affinity determination according to Jakob et al, 2000:

$$
\mathrm{Ka}_{\mathrm{P} 1 \_1-100}=\underline{\left(\text { KaTPEN } \mathrm{x}\left[\mathrm{P} 1 \_1-100 \mathrm{Zn}\right] \mathrm{x}[\mathrm{Zn} \text {-free TPEN]})\right.}
$$

[TPEN Zn] x [Zn-free P1_1-100]

Where $\mathrm{Ka}_{\mathrm{TPEN}}=10^{16} \mathrm{M}^{-1}$ (Anderegg et al, 1977), the TPEN concentrations necessary to release $50 \%$ of $\mathrm{Zn}$ atoms in P1_1-100 is determined graphically $\left(\left[\mathrm{TPEN}_{\mathrm{Zn} 50 \%}\right]=63 \times 10^{-6} \mathrm{M}\right)$. [P1_1-100 Zn] and [Znfree P1_1-100] correspond to the concentrations of proteins with or without $\mathrm{Zn}$ respectively. [P1_1$100 \mathrm{Zn}]=\left[\mathrm{Zn}\right.$-free P1_1-100] $=20 \times 10^{-6} \mathrm{M}$. [Zn-free TPEN] and [TPEN Zn] correspond to the 
concentrations of free TPEN or in complex with $\mathrm{Zn}$ atom. $[\mathrm{Zn}$-free TPEN $]=\left[\mathrm{TPEN}_{\mathrm{Zn} 50 \%}\right]-[\mathrm{Zn}-$ free P1_1-100].

\section{Native mass spectrometry}

Purified rP1 was buffer exchanged against $50 \mathrm{mM}$ ammonium acetate, $\mathrm{pH}$ 8.0, using microcentrifuge gel-filtration columns (Zeba $0.5 \mathrm{~mL}$, ThermoScientific, France) prior to MS analyses. Native MS experiments were performed on a high resolution electrospray quadrupole time-of-flight mass spectrometer (Synapt G2, Waters, Manchester, UK) equipped with an automated chip-based nanoelectrospray device (TriversaNanomate, Advion Biosciences, Ithaca, NY). Calibration was performed with the multiply charged ions produced by $2 \mu \mathrm{M}$ horse heart myoglobin diluted in 1:1 (v:v) acetonitrile:water with $1 \%$ formic acid. Molecular mass, integrity, and homogeneity of rP1 were first checked in denaturing conditions by diluting $\mathrm{rP} 1$ down to $2 \mu \mathrm{M}$ in 1:1 (v:v) acetonitrile:water acidified with $1 \%$ formic acid.

Analyses in native conditions were carried out using $5 \mu \mathrm{M}$ to $10 \mu \mathrm{M}$ of P1 and mutants in $50 \mathrm{mM}$ ammonium acetate, $\mathrm{pH}$ 8.0. Optimal acceleration voltages applied on the sample cone $(\mathrm{Vc})$ and a welladapted pressure in the interface $(\mathrm{Pi})$ was used to preserve weak noncovalent interactions in the gas phase. MS data were acquired and processed using MassLynx ${ }^{\text {TM }} 4.1$ (Waters). Peak intensities of the main charge states of the different species were used to calculate ratios of each detected species.

For EDTA treatment, rP1 $(5 \mu \mathrm{M})$ was incubated overnight at $4{ }^{\circ} \mathrm{C}$ with 40 ou 200 equivalent EDTA and $1 \mathrm{mM}$ DTT. For dynamic monitoring of zinc reversibility, EDTA-treated rP1 was incubated with $100 \mu \mathrm{M}$ zinc acetate addition.

\section{X-ray crystallography}

The purified P1_1-100 and P1_102-157 proteins were concentrated to $10 \mathrm{mg} / \mathrm{ml} \mathrm{mL}$ and $50 \mathrm{mg} / \mathrm{mL}$ respectively in $20 \mathrm{mM}$ Tris- $\mathrm{HCl} \mathrm{pH} 8,75 \mathrm{mM} \mathrm{NaCl}, 1 \mathrm{mM}$ DTT and $300 \mu \mathrm{M} \mathrm{ZnCl}_{2}$. Crystallization trials were performed at $20^{\circ} \mathrm{C}$ using the hanging-drop vapor-diffusion method in 96 microplates and nano X8 (Cartesian) robot with $100 \mathrm{nl}$ of protein mixed with $100 \mathrm{nl}$ of reservoir. After 3 weeks, small crystals of P1_1-100 were obtained from condition 35 of the Classic Suite II kit (Qiagen) containing $0.1 \mathrm{M}$ HEPES pH 7, 1 M Ammonium sulfate, and $0.5 \%(\mathrm{w} / \mathrm{v})$ PEG 8000. After further optimization, diffracting crystals were obtained from 0.1 M MES pH 6, 0.5 M Ammonium sulfate and $0.5 \%$ PEG 8000 using the hanging-drop vapor-diffusion method. Crystals were cryo-protected by flash soaking in the same solution containing $20 \%$ of 1-4 Butandiol (Sigma) before flash freezing in liquid $\mathrm{N}_{2}$. After 5 weeks, diffracting crystals of P1_102-157 were obtained at $4^{\circ} \mathrm{C}$ from condition 7 of the Classic kit (Qiagen) containing 0.1 M tri-Sodium citrate $\mathrm{pH} 5,6,20 \%(\mathrm{v} / \mathrm{v})$ Isopropanol and $20 \%(\mathrm{w} / \mathrm{v})$ PEG 4000. Crystals were cryo-protected by flash freezing in liquid $\mathrm{N}_{2}$.

\section{X-Ray data collection, processing and structure determination}


Crystal diffraction datasets were collected at the European Synchrotron Radiation Facility (ESRF, Grenoble) at beam lines ID23-1 and ID29 using a Pixel detector (Pilatus 6M) and processed by XDS (Kabsch, 2010) and Scala (Evans, 2006) from the CCP4 programs suite (Winn et al, 2011).

P1_1-100 crystals belong to the $\mathrm{F}_{1} 32$ space group and contain two molecules in the asymmetric unit. Their structure was determined to $2.10 \AA$ by the single wavelength anomalous diffraction (SAD) method using HKL2MAP (Sheldrick, 2010) and ARP/WARP (Langer et al, 2008; Murshudov et al, 2011) from the CCP4 programs suite.

P1_102-157 crystals belong to the $\mathrm{P} 12{ }_{1} 1$ space group and contain two molecules in the asymmetric unit. P1_102-157 structure was determined to 2.10 A by the single wavelength anomalous diffraction (SAD) method using AUTOSOL from PHENIX (Adams et al, 2010) and ARP/WARP and P1_102-157 phasing data set. A higher resolution structure was determined using a higher resolution dataset (P1_102-157 at 1,98 $\AA$ ) and molecular replacement with PHASER (McCoy et al, 2007).

After model building using Coot (Emsley et al, 2010) and refinement by REFINE from PHENIX, final structures exhibited an R(\%) / R(\%) free of 0,185 / 0,214 for P1_1-100 and 0,193 / 0,223 for P1_102-157. Final refinement statistics for the structures are listed in Table 2. Figures were generated using PyMol (http://www.pymol.org/).

The atomic coordinates and structure factors of P1_1-100, as well as the P1_102-157, have been deposited in the Protein Data Bank with accession numbers 6TY0 and 6TY2, respectively.

\section{Nuclear magnetic resonance analyses and structure calculations}

Production of proteins for NMR studies followed the protocol detailed in Yang et al (2019) and in Appendix Table 2. Briefly, ${ }^{15} \mathrm{~N}$-edited HSQC-TOCSY and -NOESY experiments were used to assign resonances of the short constructs. The assignment of full P1_1-157 was deduced from these experiments, except the linker region (residue $98-103$ ). ${ }^{15} \mathrm{~N} /{ }^{13} \mathrm{C} /{ }^{1} \mathrm{H}$ triple resonance experiments on the full length protein confirmed NMR resonance assignment for the $\mathrm{N}$ - and C-terminal domains and enabled the identification of chemical shifts of the linker region. Chemical shifts have been deposited in the BioMagResBank (http://www.brmb.wisc.edu) with accession number 27880.

Residual dipolar couplings were measured as differences of ${ }^{1} \mathrm{~J}_{\mathrm{HN}}$ couplings between an aligned sample with a $14 \mathrm{mg} / \mathrm{mL}$ Pf1 phage suspension (Asla ${ }^{\text {Biotech}}$ ) and an isotropic sample of ${ }^{15} \mathrm{~N}$ labelled P1_1-157. ${ }^{1} \mathrm{~J}_{\mathrm{HN}}$ couplings were measured as doubles of chemical shift differences in the ${ }^{15} \mathrm{~N}$ dimension of the ${ }^{15} \mathrm{~N}-{ }^{1} \mathrm{H}$ correlation peaks of TROSY-HSQC spectra pair (Kontaxis et al, 2000), recorded each with 128 complex points inF1, and subsequently zero-filled to 256 complex points using linear forwards prediction. Extraction of the alignment tensor parameters was performed with the Module software (Dosset et al, 2001).

${ }^{15} \mathrm{~N}$ relaxation datasets were obtained according to published pulse sequences incorporating a heating compensation scheme between T1 and T2 experiments (Farrow et al, 1994). Experiments were recorded at $20^{\circ}$, with a recycle delay of $3 \mathrm{~s}$. Delay times were $1 \mathrm{~ms}, 100 \mathrm{~ms}, 600 \mathrm{~ms}, 900 \mathrm{~ms}, 1200 \mathrm{~ms}$ 
and $1600 \mathrm{~ms}$ for the $\mathrm{T} 1$ experiments and 15.8, 31.6, 47.5 and $63.4 \mathrm{~ms}$ for the $\mathrm{T} 2$ experiments. Compensatory refocusing periods were introduced in the $\mathrm{T} 1$ and $\mathrm{T} 2$ experiments so that the spins experience an identical heating in all relaxation experiments (Mulder et al, 1999). The protein was slowly aggregating over times, leading to a slightly accelerated decay of magnetization, and resulting in an 0.94-0.96 scaling factor between two successive T2 or T1 experiments. Fits of the relaxation times were performed after a rescaling of the corresponding intensities. Estimation of the diffusion tensor was done with the Tensor software from T1/T2 ratios (Dosset et al, 2000).

Derivation of the mean structure of the whole protein was done by conjoined rigid-body/torsion angle/Cartesian simulated annealing driven by NMR restraints, according to the protocol developed by Clore and co-workers (Schwieters et al, 2010). The calculations were carried out in Xplor-NIH (Schwieters \& Clore, 2001; Schwieters et al, 2006). The residues of the 1-96 fragment were held fixed in space, whereas the 105-157 fragment was treated as a rigid body. After a randomization step of backbone dihedral angles, atoms of the linker region connecting both zinc fingers (residues 98-104) were given first Cartesian and then torsional degrees of freedom, under residual couplings, restraints derived from ${ }^{1} \mathrm{H}^{-1} \mathrm{H}$ Noes, and $\phi / \psi$ restraints derived by TALOS (Shen \& Bax, 2013) from HN, N, C $\alpha$, $\mathrm{C} \beta$ and $\mathrm{C}$ chemical shifts, in addition to covalent and geometrical energetic terms. The coordinates and experimental data have been deposited in the PDB, accession number 6XV2.

\section{Supplementary materials}

All tools and methods for $\mathrm{Y} 2 \mathrm{H}$ and BiFC experiments are described in the Appendix Materials and Methods section.

\section{Acknowledgements}

We are grateful to Pr Grishin (University of Texas, USA) and Srikrishna Subramania (CSIR-Institute of Microbial Technology, India) for helpful discussion and expertise. We thank the ID23-1 and ID29 beams lines scientists at European Synchrotron Radiation Facility (Grenoble) for their excellent support during data collections. We also thank Caroline Y.I. Hsing and Lin-Yun Kuang (IPMB Institute, Academia Sinica, Taipei, Taiwan) for training V. P. to plant protoplasts isolation, and C. Alcon (Montpellier RIO-Imaging and PHIV platforms at http://www.mri.cnrs.fr/, Montpellier-France) for confocal microscopy assistance. V. P. and F. V. are also grateful to the Franco-Taiwanese Partenariat Hubert Curien Orchid program n ${ }^{\circ} 29354$ SD, to the Taiwanese Research and Practical Training Program, and to the Gaïa PhD School of Montpellier University, France, for their financial supports. The CBS is a GIS-IBIsA platform and is member of the French Infrastructure for Integrated Structural Biology (FRISBI), a French infrastructure supported by the National Research Agency (ANR-10-INBS-05). V. P. and F-X. G. were awarded with PhD Internships from the French Ministry of Education and Scientific Research. 
bioRxiv preprint doi: https://doi.org/10.1101/2020.02.24.963488; this version posted February 25, 2020. The copyright holder for this preprint (which was not certified by peer review) is the author/funder. All rights reserved. No reuse allowed without permission.

\section{Réferences}

Abubakar Z, Ali F, Pinel A, Traoré O, N'Guessan P, Notteghem J-L, Kimmins F, Konaté G \& Fargette D (2003) Phylogeography of Rice yellow mottle virus in Africa. J. Gen. Virol. 84: 733743

Adams PD, Afonine P V., Bunkóczi G, Chen VB, Davis IW, Echols N, Headd JJ, Hung L-W, Kapral GJ, Grosse-Kunstleve RW, McCoy AJ, Moriarty NW, Oeffner R, Read RJ, Richardson DC, Richardson JS, Terwilliger TC \& Zwart PH (2010) PHENIX: a comprehensive Python-based system for macromolecular structure solution. Acta Crystallogr. Sect. D Biol. Crystallogr. 66: 213-221

Anderegg G, Hubmann E, Podder NG \& Wenk F (1977) Pyridinderivate als Komplexbildner. XI. Die Thermodynamik der Metallkomplexbildung mit Bis-, Tris- und Tetrakis[(2-pyridyl)methyl]aminen. Helv. Chim. Acta 60: 123-140

Azevedo J, Garcia D, Pontier D, Ohnesorge S, Yu A, Garcia S, Braun L, Bergdoll M, Hakimi MA, Lagrange T \& Voinnet O (2010) Argonaute quenching and global changes in Dicer homeostasis caused by a pathogen-encoded GW repeat protein. Genes Dev. 24: 904-915

Bakker W (1970) Rice yellow mottle, a mechanically transmissible virus disease of rice in Kenya. Netherlands J. Plant Pathol. 76: 53-63

Barbirz S, Jakob U \& Glocker MO (2000) Mass Spectrometry Unravels Disulfide Bond Formation as the Mechanism That Activates a Molecular Chaperone. J. Biol. Chem. 275: 18759-18766

Baril M \& Brakier-Gingras L (2005) Translation of the F protein of hepatitis C virus is initiated at a non-AUG codon in a +1 reading frame relative to the polyprotein. Nucleic Acids Res. 33: 1474 1486

Baulcombe DC \& Molnár A (2004) Crystal structure of p19 - a universal suppressor of RNA silencing. Trends Biochem. Sci. 29: 279-281

Baumberger N, Tsai C-H, Lie M, Havecker E \& Baulcombe DC (2007) The Polerovirus Silencing Suppressor P0 Targets ARGONAUTE Proteins for Degradation. Curr. Biol. 17: 1609-1614

Belshaw R, Pybus OG \& Rambaut A (2007) The evolution of genome compression and genomic novelty in RNA viruses. Genome Res. 17: 1496-1504

Ben-Shaul A \& Gelbart WM (2015) Viral ssRNAs Are Indeed Compact. Biophys. J. 108: 14-16

Bonneau C, Brugidou C, Chen L, Beachy RN \& Fauquet C (1998) Expression of the rice yellow mottle virus P1 protein in vitro and in vivo and its involvement in virus spread. Virology 244: 79-86

Bortolamiol D, Pazhouhandeh M, Marrocco K, Genschik P \& Ziegler-Graff V (2007) The Polerovirus F box protein P0 targets ARGONAUTE1 to suppress RNA silencing. Curr. Biol. 17: 1615-21

Brierley I (1995) Ribosomal frameshifting on viral RNAs. J. Gen. Virol. 76: 1885-1892

Brugidou C, Holt C, Yassi MN, Zhang S, Beachy R \& Fauquet C (1995) Synthesis of an infectious full-length cDNA clone of rice yellow mottle virus and mutagenesis of the coat protein. Virology 206: $108-15$

Carrington JC, Kasschau KD, Mahajan SK \& Schaad MC (1996) Cell-to-Cell and Long-Distance Transport of Viruses in Plants. Plant Cell 8: 1669-1681 
bioRxiv preprint doi: https://doi.org/10.1101/2020.02.24.963488; this version posted February 25, 2020. The copyright holder for this preprint (which was not certified by peer review) is the author/funder. All rights reserved. No reuse allowed without permission.

Chao JA, Lee JH, Chapados BR, Debler EW, Schneemann A \& Williamson JR (2005) Dual modes of RNA-silencing suppression by Flock House virus protein B2. Nat. Struct. Mol. Biol. 12: 952-7

Chen H-Y, Yang J, Lin C \& Yuan YA (2008) Structural basis for RNA-silencing suppression by Tomato aspermy virus protein 2b. EMBO Rep. 9: 754-760

Chen J, Sawyer N \& Regan L (2013) Protein-protein interactions: General trends in the relationship between binding affinity and interfacial buried surface area. Protein Sci. 22: 510-515

Chiba S, Hleibieh K, Delbianco A, Klein E, Ratti C, Ziegler-Graff V, Bouzoubaa S \& Gilmer D (2013) The Benyvirus RNA Silencing Suppressor Is Essential for Long-Distance Movement, Requires Both Zinc-Finger and NoLS Basic Residues but Not a Nucleolar Localization for Its Silencing-Suppression Activity. Mol. Plant-Microbe Interact. 26: 168-181

Clare DK, Pechnikova EV, Skurat EV, Makarov VV, Sokolova OS, Solovyev AG \& Orlova EV (2015) Novel Inter-Subunit Contacts in Barley Stripe Mosaic Virus Revealed by Cryo-Electron Microscopy. Structure 23: 1815-1826

Csorba T, Kontra L \& Burgyán J (2015) Viral silencing suppressors: Tools forged to fine-tune hostpathogen coexistence. Virology 479-480: $85-103$

Demene H, Dong CZ, Ottmann M, Rouyez MC, Jullian N, Morellet N, Mely Y, Darlix JL \& FournieZaluski MC (1994) 1H NMR structure and biological studies of the His23 .fwdarw. Cys mutant nucleocapsid protein of HIV-1 indicate that the conformation of the first zinc finger is critical for virus infectivity. Biochemistry 33: 11707-11716

Deng P, Wu Z \& Wang A (2015) The multifunctional protein CI of potyviruses plays interlinked and distinct roles in viral genome replication and intercellular movement. Virol. J. 12: 141

DiMaio F, Chen C-C, Yu X, Frenz B, Hsu Y-H, Lin N-S \& Egelman EH (2015) The molecular basis for flexibility in the flexible filamentous plant viruses. Nat. Struct. Mol. Biol. 22: 642-644

Ding S-W \& Voinnet O (2007) Antiviral Immunity Directed by Small RNAs. Cell 130: 413-426

Dong X, van Wezel R, Stanley J \& Hong Y (2003) Functional characterization of the nuclear localization signal for a suppressor of posttranscriptional gene silencing. J. Virol. 77: 7026-33

Dosset P, Hus JC, Blackledge M \& Marion D (2000) Efficient analysis of macromolecular rotational diffusion from heteronuclear relaxation data. J. Biomol. NMR 16: 23-8

Dosset P, Hus JC, Marion D \& Blackledge M (2001) A novel interactive tool for rigid-body modeling of multi-domain macromolecules using residual dipolar couplings. J. Biomol. NMR 20: 223-31

Dreher TW \& Miller WA (2006) Translational control in positive strand RNA plant viruses. Virology 344: $185-197$

El-Shami M, Pontier D, Lahmy S, Braun L, Picart C, Vega D, Hakimi M-A, Jacobsen SE, Cooke R \& Lagrange T (2007) Reiterated WG/GW motifs form functionally and evolutionarily conserved ARGONAUTE-binding platforms in RNAi-related components. Genes Dev. 21: 2539-44

Emsley P, Lohkamp B, Scott WG \& Cowtan K (2010) Features and development of Coot. Acta Crystallogr. Sect. D Biol. Crystallogr. 66: 486-501

Evans P (2006) Scaling and assessment of data quality. Acta Crystallogr. Sect. D Biol. Crystallogr. 62: $72-82$

Fargette D, Pinel A, Abubakar Z, Traoré O, Brugidou C, Fatogoma S, Hébrard E, Choisy M, Séré Y, Fauquet $C \&$ Konaté $\mathrm{G}$ (2004) Inferring the evolutionary history of rice yellow mottle virus from 
bioRxiv preprint doi: https://doi.org/10.1101/2020.02.24.963488; this version posted February 25, 2020. The copyright holder for this preprint (which was not certified by peer review) is the author/funder. All rights reserved. No reuse allowed without permission.

genomic, phylogenetic, and phylogeographic studies. J. Virol. 78: 3252-61

Farrow NA, Muhandiram R, Singer AU, Pascal SM, Kay CM, Gish G, Shoelson SE, Pawson T, Forman-Kay JD \& Kay LE (1994) Backbone dynamics of a free and phosphopeptide-complexed Src homology 2 domain studied by 15N NMR relaxation. Biochemistry 33: 5984-6003

Firth AE \& Brierley I (2012) Non-canonical translation in RNA viruses. J. Gen. Virol. 93: 1385-409

Fujita N, Komatsu K, Ayukawa Y, Matsuo Y, Hashimoto M, Netsu O, Teraoka T, Yamaji Y, Namba $\mathrm{S} \&$ Arie T (2018) N-terminal region of cysteine-rich protein (CRP) in carlaviruses is involved in the determination of symptom types. Mol. Plant Pathol. 19: 180-190

Fusaro AF, Correa RL, Nakasugi K, Jackson C, Kawchuk L, Vaslin MFS \& Waterhouse PM (2012) The Enamovirus P0 protein is a silencing suppressor which inhibits local and systemic RNA silencing through AGO1 degradation. Virology 426: 178-87

Ghosh S, Kaushik A, Khurana S, Varshney A, Singh AK, Dahiya P, Thakur JK, Sarin SK, Gupta D, Malhotra P, Mukherjee SK \& Bhatnagar RK (2017) An RNAi-based high-throughput screening assay to identify small molecule inhibitors of hepatitis B virus replication. J. Biol. Chem. 292: $12577-12588$

Gillet F-X, Cattoni DI, Petiot-Bécard S, Delalande F, Poignavent V, Brizard J-P, Bessin Y, Dorsselaer A Van, Declerck N, Sanglier-Cianférani S, Brugidou C \& Vignols F (2013) The RYMV-encoded viral suppressor of RNA silencing P1 is a zinc-binding protein with redox-dependent flexibility. J. Mol. Biol. 425: 2423-35

Graumann J, Lilie H, Tang X, Tucker KA, Hoffmann JH, Vijayalakshmi J, Saper M, Bardwell JC \& Jakob U (2001) Activation of the redox-regulated molecular chaperone Hsp33--a two-step mechanism. Structure 9: 377-87

Harries P \& Ding B (2011) Cellular factors in plant virus movement: At the leading edge of macromolecular trafficking in plants. Virology 411: 237-243

Heinlein M (2015) Plant virus replication and movement. Virology 479-480: 657-671

Hesketh EL, Meshcheriakova Y, Dent KC, Saxena P, Thompson RF, Cockburn JJ, Lomonossoff GP \& Ranson NA (2015) Mechanisms of assembly and genome packaging in an RNA virus revealed by high-resolution cryo-EM. Nat. Commun. 6: 10113

Holm L \& Rosenström P (2010) Dali server: Conservation mapping in 3D. Nucleic Acids Res. 38: W545-W549

Holmes EC (2003) Error thresholds and the constraints to RNA virus evolution. Trends Microbiol. 11: $543-6$

Ilbert M, Horst J, Ahrens S, Winter J, Graf PCF, Lilie H \& Jakob U (2007) The redox-switch domain of Hsp33 functions as dual stress sensor. Nat. Struct. Mol. Biol. 14: 556-63

Jabbar B, Iqbal MS, Batcho AA, Nasir IA, Rashid B, Husnain T \& Henry RJ (2019) Target prediction of candidate miRNAs from Oryza sativa for silencing the RYMV genome. Comput. Biol. Chem. 83: 107127

Jakob U, Eser M \& Bardwell JC (2000) Redox switch of hsp33 has a novel zinc-binding motif. J. Biol. Chem. 275: 38302-10

Kabsch W (2010) Integration, scaling, space-group assignment and post-refinement. Acta Crystallogr. Sect. D Biol. Crystallogr. 66: 133-144 
bioRxiv preprint doi: https://doi.org/10.1101/2020.02.24.963488; this version posted February 25, 2020. The copyright holder for this preprint (which was not certified by peer review) is the author/funder. All rights reserved. No reuse allowed without permission.

Kaur G \& Subramanian S (2016) Classification of the treble clef zinc finger: noteworthy lessons for structure and function evolution. Sci. Rep. 6: 32070

Kelly SM, Jess TJ \& Price NC (2005) How to study proteins by circular dichroism. Biochim. Biophys. Acta - Proteins Proteomics 1751: 119-139

Kenesi E, Carbonell A, Lózsa R, Vértessy B \& Lakatos L (2017) A viral suppressor of RNA silencing inhibits ARGONAUTE 1 function by precluding target RNA binding to pre-assembled RISC. Nucleic Acids Res. 45: 7736-7750

Kontaxis G, Clore GM \& Bax A (2000) Evaluation of cross-correlation effects and measurement of one-bond couplings in proteins with short transverse relaxation times. J. Magn. Reson. 143: 18496

Krishna SS, Majumdar I \& Grishin N V (2003) Structural classification of zinc fingers: survey and summary. Nucleic Acids Res. 31: 532-50

Lacombe S, Bangratz M, Vignols F \& Brugidou C (2010) The rice yellow mottle virus P1 protein exhibits dual functions to suppress and activate gene silencing. Plant J. 61: 371-82

Lakatos L, Csorba T, Pantaleo V, Chapman EJ, Carrington JC, Liu Y-P, Dolja V V, Calvino LF, López-Moya JJ \& Burgyán J (2006) Small RNA binding is a common strategy to suppress RNA silencing by several viral suppressors. EMBO J. 25: 2768-2780

Langer G, Cohen SX, Lamzin VS \& Perrakis A (2008) Automated macromolecular model building for X-ray crystallography using ARP/wARP version 7. Nat. Protoc. 3: 1171-9

Lee J-W \& Helmann JD (2006) Biochemical characterization of the structural Zn2+ site in the Bacillus subtilis peroxide sensor PerR. J. Biol. Chem. 281: 23567-78

Li W, Bottrill AR, Bibb MJ, Buttner MJ, Paget MSB \& Kleanthous C (2003) The Role of Zinc in the Disulphide Stress-regulated Anti-sigma Factor RsrA from Streptomyces coelicolor. J. Mol. Biol. 333: $461-472$

Ling R, Pate AE, Carr JP \& Firth AE (2013) An essential fifth coding ORF in the sobemoviruses. Virology 446: $397-408$

López C, Navas-Castillo J, Gowda S, Moreno P \& Flores R (2000) The 23-kDa Protein Coded by the 3'-Terminal Gene of Citrus Tristeza Virus Is an RNA-Binding Protein. Virology 269: 462-470

Löwer R, Tönjes RR, Korbmacher C, Kurth R \& Löwer J (1995) Identification of a Rev-related protein by analysis of spliced transcripts of the human endogenous retroviruses HTDV/HERV-K. J. Virol. 69: 141-9

Lukhovitskaya NI, Thaduri S, Garushyants SK, Torrance L \& Savenkov EI (2013) Deciphering the mechanism of defective interfering RNA (DI RNA) biogenesis reveals that a viral protein and the DI RNA act antagonistically in virus infection. J. Virol. 87: 6091-103

McCoy AJ, Grosse-Kunstleve RW, Adams PD, Winn MD, Storoni LC \& Read RJ (2007) Phaser crystallographic software. J. Appl. Crystallogr. 40: 658-674

Mekdad H El, Boutant E, Karnib H, Biedma ME, Sharma KK, Malytska I, Laumond G, Roy M, Réal E, Paillart J-C, Moog C, Darlix JL, Mély Y \& de Rocquigny H (2016) Characterization of the interaction between the HIV-1 Gag structural polyprotein and the cellular ribosomal protein L7 and its implication in viral nucleic acid remodeling. Retrovirology 13: 54

Mulder FAA, van Tilborg PJA, Kaptein R \& Boelens R (1999) Microsecond time scale dynamics in the RXR DNA-binding domain from a combination of spin-echo and off-resonance rotating 
bioRxiv preprint doi: https://doi.org/10.1101/2020.02.24.963488; this version posted February 25, 2020. The copyright holder for this preprint (which was not certified by peer review) is the author/funder. All rights reserved. No reuse allowed without permission.

frame relaxation measurements. J. Biomol. NMR 13: 275-288

Murshudov GN, Skubák P, Lebedev AA, Pannu NS, Steiner RA, Nicholls RA, Winn MD, Long F \& Vagin AA (2011) REFMAC 5 for the refinement of macromolecular crystal structures. Acta Crystallogr. Sect. D Biol. Crystallogr. 67: 355-367

Ndjiondjop MN, Albar L, Fargette D, Fauquet C \& Ghesquière A (1999) The Genetic Basis of High Resistance to Rice Yellow Mottle Virus (RYMV) in Cultivars of Two Cultivated Rice Species. Plant Dis. 83: 931-935

Negi S, Itazu M, Imanishi M, Nomura A \& Sugiura Y (2004) Creation and characteristics of unnatural CysHis(3)-type zinc finger protein. Biochem. Biophys. Res. Commun. 325: 421-5

Nummert G, Sõmera M, Uffert G, Abner E \& Truve E (2017) P1-independent replication and local movement of Rice yellow mottle virus in host and non-host plant species. Virology 502: 28-32

Paget MS, Bae JB, Hahn MY, Li W, Kleanthous C, Roe JH \& Buttner MJ (2001) Mutational analysis of RsrA, a zinc-binding anti-sigma factor with a thiol-disulphide redox switch. Mol. Microbiol. 39: $1036-47$

Plisson C, Drucker M, Blanc S, German-Retana S, Le Gall O, Thomas D \& Bron P (2003) Structural Characterization of HC-Pro, a Plant Virus Multifunctional Protein. J. Biol. Chem. 278: 2375323761

Pumplin N \& Voinnet O (2013) RNA silencing suppression by plant pathogens: defence, counterdefence and counter-counter-defence. Nat. Rev. Microbiol. 11: 745-760

Pushker R, Mooney C, Davey NE, Jacqué J-M \& Shields DC (2013) Marked variability in the extent of protein disorder within and between viral families. PLoS One 8: e60724

Rajasekar K V, Zdanowski K, Yan J, Hopper JTS, Francis M-LR, Seepersad C, Sharp C, Pecqueur L, Werner JM, Robinson C V, Mohammed S, Potts JR \& Kleanthous C (2016) The anti-sigma factor RsrA responds to oxidative stress by reburying its hydrophobic core. Nat. Commun. 7: 12194

Rakotomalala M, Vrancken B, Pinel-Galzi A, Ramavovololona P, Hébrard E, Randrianangaly JS, Dellicour S, Lemey P \& Fargette D (2019) Comparing patterns and scales of plant virus phylogeography: Rice yellow mottle virus in Madagascar and in continental Africa. Virus Evol. 5: vez023

Rantalainen KI, Eskelin K, Tompa P \& Makinen K (2011) Structural Flexibility Allows the Functional Diversity of Potyvirus Genome-Linked Protein VPg. J. Virol. 85: 2449-2457

Ren B, Guo Y, Gao F, Zhou P, Wu F, Meng Z, Wei C \& Li Y (2010) Multiple Functions of Rice Dwarf Phytoreovirus Pns 10 in Suppressing Systemic RNA Silencing. J. Virol. 84: 12914-12923

de Rocquigny H, Petitjean P, Tanchou V, Decimo D, Drouot L, Delaunay T, Darlix J-L \& Roques BP (1997) The Zinc Fingers of HIV Nucleocapsid Protein NCp7 Direct Interactions with the Viral Regulatory Protein Vpr. J. Biol. Chem. 272: 30753-30759

Schwieters CD \& Clore GM (2001) Internal Coordinates for Molecular Dynamics and Minimization in Structure Determination and Refinement. J. Magn. Reson. 152: 288-302

Schwieters CD, Kuszewski JJ \& Marius Clore G (2006) Using Xplor-NIH for NMR molecular structure determination. Prog. Nucl. Magn. Reson. Spectrosc. 48: 47-62

Schwieters CD, Suh J-Y, Grishaev A, Ghirlando R, Takayama Y \& Clore GM (2010) Solution Structure of the $128 \mathrm{kDa}$ Enzyme I Dimer from Escherichia coli and Its $146 \mathrm{kDa}$ Complex with 
bioRxiv preprint doi: https://doi.org/10.1101/2020.02.24.963488; this version posted February 25, 2020. The copyright holder for this preprint (which was not certified by peer review) is the author/funder. All rights reserved. No reuse allowed without permission.

HPr Using Residual Dipolar Couplings and Small- and Wide-Angle X-ray Scattering. J. Am. Chem. Soc. 132: 13026-13045

Sereme D, Lacombe S, Konate M, Bangratz M, Pinel-Galzi A, Fargette D, Traore AS, Konate G \& Brugidou C (2014) Sites under positive selection modulate the RNA silencing suppressor activity of rice yellow mottle virus movement protein P1. J. Gen. Virol. 95: 213-218

Sérémé D, Lacombe S, Konate M, Bangratz M, Pinel-Galzi A, Fargette D, Traore AS, Konate G \& Brugidou C (2014) Sites under positive selection modulate the RNA silencing suppressor activity of rice yellow mottle virus movement protein P1. J. Gen. Virol. 95: 213-218

Sheldrick GM (2010) Experimental phasing with SHELXC / D / E : combining chain tracing with density modification. Acta Crystallogr. Sect. D Biol. Crystallogr. 66: 479-485

Shen Y \& Bax A (2013) Protein backbone and sidechain torsion angles predicted from NMR chemical shifts using artificial neural networks. J. Biomol. NMR 56: 227-241

Siré C, Bangratz-Reyser M, Fargette D \& Brugidou C (2008) Genetic diversity and silencing suppression effects of Rice yellow mottle virus and the P1 protein. Virol. J. 5: 55

Smith RM \& Martell AE (1989) Iminodiacetic Acid Derivatives. In Critical Stability Constants pp 67-127. Boston, MA: Springer US

Sõmera M, Sarmiento C \& Truve E (2015) Overview on Sobemoviruses and a Proposal for the Creation of the Family Sobemoviridae. Viruses 7: 3076-3115

Sorel M, Garcia JA \& German-Retana S (2014) The Potyviridae Cylindrical Inclusion Helicase: A Key Multipartner and Multifunctional Protein. Mol. Plant-Microbe Interact. 27: 215-226

Sztuba-Solińska J, Stollar V \& Bujarski JJ (2011) Subgenomic messenger RNAs: Mastering regulation of (+)-strand RNA virus life cycle. Virology 412: 245-255

Taliansky M, Torrance L \& Kalinina NO (2008) Role of Plant Virus Movement Proteins. In Methods in molecular biology (Clifton, N.J.) pp 33-54.

Till S, Lejeune E, Thermann R, Bortfeld M, Hothorn M, Enderle D, Heinrich C, Hentze MW \& Ladurner AG (2007) A conserved motif in Argonaute-interacting proteins mediates functional interactions through the Argonaute PIWI domain. Nat. Struct. Mol. Biol. 14: 897-903

Tolman JR, Al-Hashimi HM, Kay LE \& Prestegard JH (2001) Structural and Dynamic Analysis of Residual Dipolar Coupling Data for Proteins.

Traore O, Sorho F, Pinel A, Abubakar Z, Banwo O, Maley J, Hebrad E, Winter S, Sere Y, Konate G \& Fargette D (2005) Processes of diversification and dispersion of Rice yellow mottle virus inferred from large-scale and high-resolution phylogeographical studies. Mol. Ecol. 14: 20972110

Trinks D, Rajeswaran R, Shivaprasad P V., Akbergenov R, Oakeley EJ, Veluthambi K, Hohn T \& Pooggin MM (2005) Suppression of RNA Silencing by a Geminivirus Nuclear Protein, AC2, Correlates with Transactivation of Host Genes. J. Virol. 79: 2517-2527

Valli A, Dujovny G \& García JA (2008) Protease activity, self interaction, and small interfering RNA binding of the silencing suppressor $\mathrm{p} 1 \mathrm{~b}$ from cucumber vein yellowing ipomovirus. J. Virol. 82: 974-86

Valli AA, Gallo A, Rodamilans B, López-Moya JJ \& García JA (2018) The HCPro from the Potyviridae family: an enviable multitasking Helper Component that every virus would like to have. Mol. Plant Pathol. 19: 744-763 
bioRxiv preprint doi: https://doi.org/10.1101/2020.02.24.963488; this version posted February 25, 2020. The copyright holder for this preprint (which was not certified by peer review) is the author/funder. All rights reserved. No reuse allowed without permission.

Vargason JM, Szittya G, Burgyán J \& Hall TMT (2003) Size selective recognition of siRNA by an RNA silencing suppressor. Cell 115: 799-811

Verchot-Lubicz J, Torrance L, Solovyev AG, Morozov SY, Jackson AO \& Gilmer D (2010) Varied Movement Strategies Employed by Triple Gene Block-Encoding Viruses. Mol. Plant-Microbe Interact. 23: $1231-1247$

Voinnet O, Pinto YM \& Baulcombe DC (1999) Suppression of gene silencing: a general strategy used by diverse DNA and RNA viruses of plants. Proc. Natl. Acad. Sci. U. S. A. 96: 14147-52

Waigmann E, Ueki S, Trutnyeva K \& Citovsky V (2004) The Ins and Outs of Nondestructive Cell-toCell and Systemic Movement of Plant Viruses. CRC. Crit. Rev. Plant Sci. 23: 195-250

Wang C-Y, Zhang Q-F, Gao Y-Z, Zhou X-P, Ji G, Huang X-J, Hong J \& Zhang C-X (2015) Insight into the three-dimensional structure of maize chlorotic mottle virus revealed by Cryo-EM single particle analysis. Virology 485: 171-178

van Wezel R, Dong X, Liu H, Tien P, Stanley J \& Hong Y (2002) Mutation of Three Cysteine Residues in Tomato yellow leaf curl virus-China C2 Protein Causes Dysfunction in Pathogenesis and Posttranscriptional Gene-Silencing Suppression. Mol. Plant-Microbe Interact. 15: 203-208

Van Wezel R, Liu H, Wu Z, Stanley J \& Hong Y (2003) Contribution of the zinc finger to zinc and DNA binding by a suppressor of posttranscriptional gene silencing. J. Virol. 77: 696-700

Winn MD, Ballard CC, Cowtan KD, Dodson EJ, Emsley P, Evans PR, Keegan RM, Krissinel EB, Leslie AGW, McCoy A, McNicholas SJ, Murshudov GN, Pannu NS, Potterton EA, Powell HR, Read RJ, Vagin A \& Wilson KS (2011) Overview of the CCP 4 suite and current developments. Acta Crystallogr. Sect. D Biol. Crystallogr. 67: 235-242

Winter J, Ilbert M, Graf PCF, Özcelik D \& Jakob U (2008) Bleach Activates a Redox-Regulated Chaperone by Oxidative Protein Unfolding. Cell 135: 691-701

Xia Z, Zhu Z, Zhu J \& Zhou R (2009) Recognition mechanism of siRNA by viral p19 suppressor of RNA silencing: a molecular dynamics study. Biophys. J. 96: 1761-9

Xu Z, Choi J, Yen TS, Lu W, Strohecker A, Govindarajan S, Chien D, Selby MJ \& Ou J (2001) Synthesis of a novel hepatitis C virus protein by ribosomal frameshift. EMBO J. 20: 3840-8

Xue B, Blocquel D, Habchi J, Uversky A V., Kurgan L, Uversky VN \& Longhi S (2014) Structural Disorder in Viral Proteins. Chem. Rev. 114: 6880-6911

Xue B, Williams RW, Oldfield CJ, Goh GK-M, Dunker AK \& Uversky VN (2010) Viral disorder or disordered viruses: do viral proteins possess unique features? Protein Pept. Lett. 17: 932-51

Yambao MLM, Yagihashi H, Sekiguchi H, Sekiguchi T, Sasaki T, Sato M, Atsumi G, Tacahashi Y, Nakahara KS \& Uyeda I (2008) Point mutations in helper component protease of clover yellow vein virus are associated with the attenuation of RNA-silencing suppression activity and symptom expression in broad bean. Arch. Virol. 153: 105-15

Yang X, Baliji S, Buchmann RC, Wang H, Lindbo JA, Sunter G \& Bisaro DM (2007) Functional modulation of the geminivirus AL2 transcription factor and silencing suppressor by selfinteraction. J. Virol. 81: 11972-81

Yang X, Tan SH, Teh YJ \& Yuan YA (2011) Structural implications into dsRNA binding and RNA silencing suppression by NS3 protein of Rice Hoja Blanca Tenuivirus. RNA 17: 903-911

Ye K, Malinina L \& Patel DJ (2003) Recognition of small interfering RNA by a viral suppressor of RNA silencing. Nature 426: $874-878$ 
Ye K \& Patel DJ (2005) RNA Silencing Suppressor p21 of Beet Yellows Virus Forms an RNA Binding Octameric Ring Structure. Structure 13: 1375-1384

Zhang X, Yuan Y-R, Pei Y, Lin S-S, Tuschl T, Patel DJ \& Chua N-H (2006) Cucumber mosaic virusencoded $2 \mathrm{~b}$ suppressor inhibits Arabidopsis Argonaute1 cleavage activity to counter plant defense. Genes Dev. 20: 3255-3268 
bioRxiv preprint doi: https://doi.org/10.1101/2020.02.24.963488; this version posted February 25, 2020. The copyright holder for this preprint (which was not certified by peer review) is the author/funder. All rights reserved. No reuse allowed without permission.

Poignavent et al, Figure 1

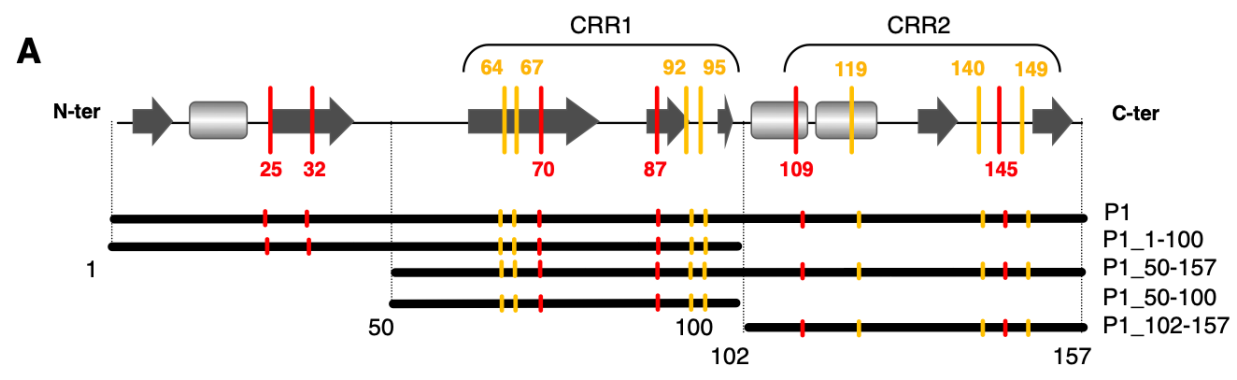

B
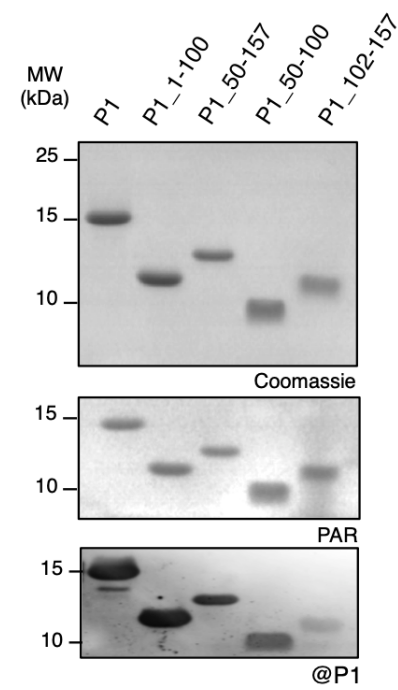
Poignavent et al., Table 1

\begin{tabular}{|c|c|c|c|c|c|c|c|c|c|}
\hline $\mathrm{P} 1$ proteins & $\begin{array}{c}\text { Theoretical } \\
\text { molecular } \\
\text { mass }\end{array}$ & $\begin{array}{c}\text { Molecular mass } \\
\text { by denaturing } \\
\text { ESI-MS }\end{array}$ & $\begin{array}{c}\text { Molecular mass by } \\
\text { native ESI-MS } \\
\text { before EDTA }\end{array}$ & $\begin{array}{l}\text { Difference } \\
\text { between native } \\
\text { ESI-MS and } \\
\text { theoretical mass }\end{array}$ & $\begin{array}{c}\text { Number of } \\
\text { zinc atoms } \\
\text { (63 to 65 Da) } \\
\text { before EDTA }\end{array}$ & $\begin{array}{c}\text { Molecular mass by } \\
\text { native ESI-MS } \\
\text { after EDTA }\end{array}$ & $\begin{array}{l}\text { Number of } \\
\text { zinc atoms } \\
\text { (63 to } 65 \mathrm{Da} \text { ) } \\
\text { after EDTA }\end{array}$ & $\begin{array}{c}\text { Molecular mass by } \\
\text { native ESI-MS } \\
\text { after EDTA }+ \\
\text { ZnOAc treatment }\end{array}$ & $\begin{array}{l}\text { Number of } \\
\text { zinc atoms } \\
\text { (63 to } 65 \mathrm{Da})\end{array}$ \\
\hline $\mathrm{P} 1$ & 17929.01 & $17928,2 \pm 0,1$ & $18056.1 \pm 0.3$ & 127,09 & 2 & $17992.2 \pm 0.3$ & 1 & $18056.6 \pm 0.4$ & 2 \\
\hline P1_1-100 & 11408.80 & $11408,81 \pm 0,31$ & $11471.66 \pm 0.04$ & 62,86 & 1 & $11472.61 \pm 0.84$ & 1 & - & - \\
\hline P1_50-100 & 5816.57 & $5816,13 \pm 0,01$ & $5880.1 \pm 0.3$ & 63,53 & 1 & No signal & - & No signal & - \\
\hline P1_50-157 & 12336.78 & $12338,12 \pm 0,39$ & $12462.3 \pm 0.3$ & 125,52 & 2 & No signal & - & No signal & - \\
\hline P1_102-157 & 6556.26 & $6555,8 \pm 0,4$ & $6620.31 \pm 0.22$ & 64,05 & 1 & $6556.46 \pm 0.4$ & 0 & $6620.34 \pm 0.27$ & 1 \\
\hline
\end{tabular}


Poignavent et al, Figure 2

A

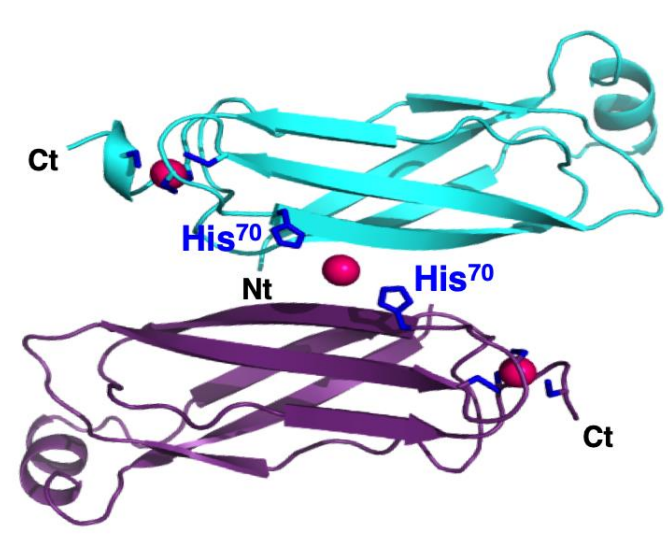

B

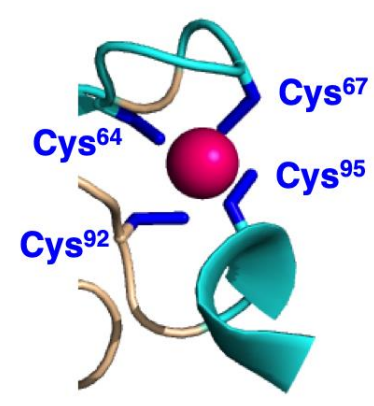

C

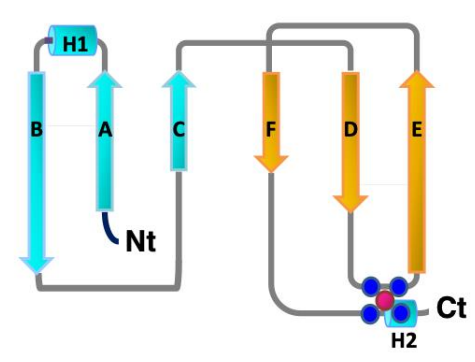

D

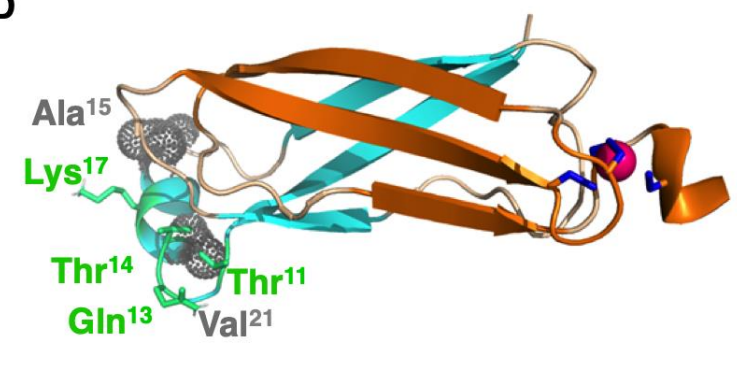

E

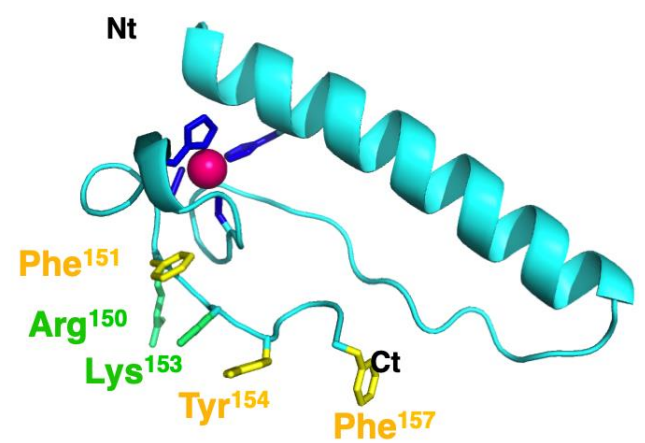

$\mathbf{F}$

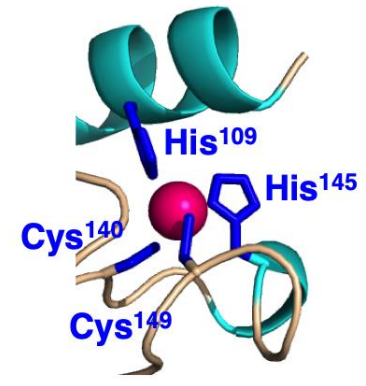


Poignavent et al., Table 2

\begin{tabular}{|c|c|c|c|}
\hline & P1_1-100 & P1_102-157-phasing & P1_102-157 \\
\hline \multicolumn{4}{|l|}{ Data collection } \\
\hline Wavelength $(\AA)$ & 0.976 & 1.28 & 1.24 \\
\hline Space group & F 4132 & P 1211 & P 1211 \\
\hline \multicolumn{4}{|l|}{ Cell dimensions } \\
\hline $\mathrm{a}, \mathrm{b}, \mathrm{c}(\AA)$ & 195.61 & $38.14 \quad 31.23 \quad 42.03$ & \\
\hline$\alpha, \beta, \gamma\left({ }^{\circ}\right)$ & & 90.00101 .0890 .00 & $\begin{array}{lll}90.00 & 101.10 & 90.00\end{array}$ \\
\hline Resolution $(\AA)^{\mathrm{a}}$ & $112.94-2.10(2.21-2.10)$ & $41.25-2.10(2.21-2.10)$ & $37.37-1.98(2.09-1.98)$ \\
\hline Rmerge & $0.051(0.559)$ & $0.154(0.448)$ & $0.098(0.573)$ \\
\hline $\mathrm{N}^{\circ}$ of reflections & $724744(104965)$ & $55242(7957)$ & $22349(3282)$ \\
\hline $\mathrm{N}^{\circ}$ of unique reflections & $19296(2756)$ & $5834(839)$ & $6911(992)$ \\
\hline$I / \mathrm{s} I$ & $8.3(1.1)$ & $12.4(5.0)$ & $8.6(2.0)$ \\
\hline Completeness (\%) & $99.97(100.0)$ & $100.0(99.9)$ & $99.2(99.4)$ \\
\hline Multiplicity & $37.5(38.1)$ & $9.5(9.5)$ & \\
\hline Anomalous completeness & $100.0(100.0)$ & $99.9(99.9)$ & \\
\hline Anomalous multiplicity & $20.1(19.9)$ & $4.6(4.5)$ & \\
\hline \multicolumn{4}{|l|}{ Refinement } \\
\hline $\mathrm{R}_{\text {work }} / \mathrm{R}_{\text {free }}(\%)$ & $0.185 / 0.214$ & & $0.193 / 0.227$ \\
\hline $\mathrm{N}^{\circ}$ atoms & 1688 & & 899 \\
\hline Protein & 1547 & & 847 \\
\hline $\mathrm{Zn}$ & 3 & & 2 \\
\hline Water & 140 & & 50 \\
\hline \multicolumn{4}{|l|}{ B-factors $\left(\AA^{2}\right)$} \\
\hline Protein & 45 & & 27 \\
\hline $\mathrm{Zn}$ & 52 & & 22 \\
\hline Water & 53 & & 29 \\
\hline \multicolumn{4}{|l|}{ rmsd } \\
\hline Bond lengths $(\AA)$ & 0.009 & & 0.007 \\
\hline Bond angles $\left({ }^{\circ}\right)$ & 1.166 & & 1.069 \\
\hline Ramachandran favored (\%) & 98.95 & & 97.88 \\
\hline Ramachandran outliers (\%) & 0.0 & & 0.0 \\
\hline
\end{tabular}


Poignavent et al, Figure 3

A

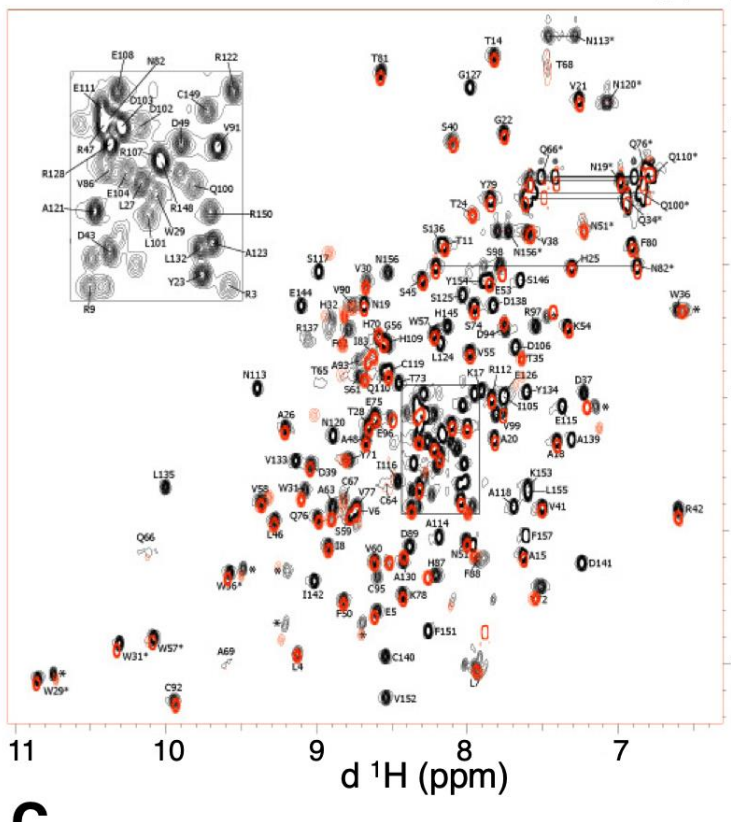
$\mathrm{d}^{15} \mathrm{~N}(\mathrm{ppm})$

$\mathrm{d}^{15} \mathrm{~N}(\mathrm{ppm})$

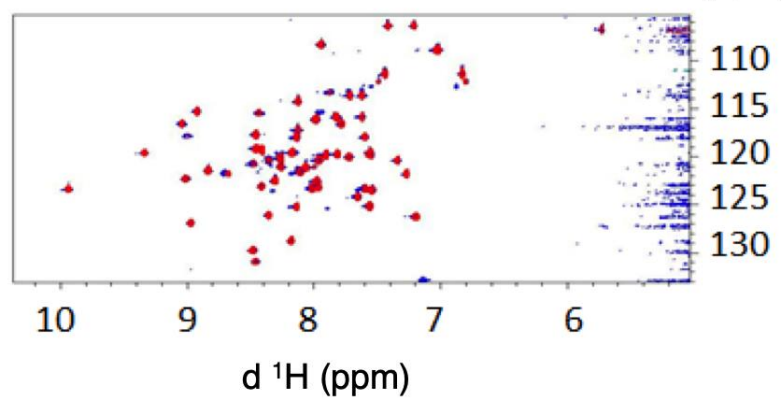

E

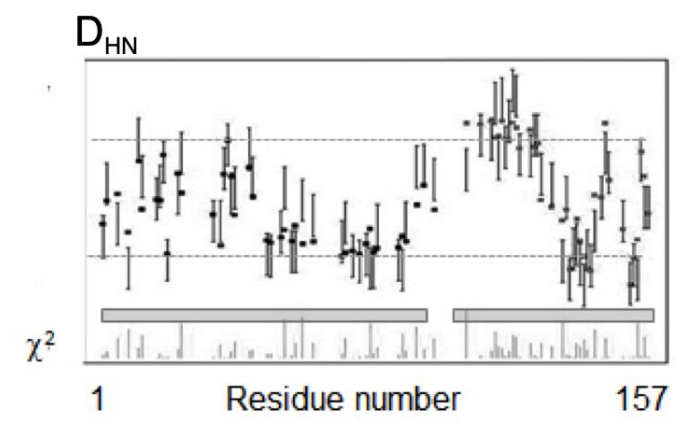

130
B $d^{15} \mathrm{~N}$ (ppm)
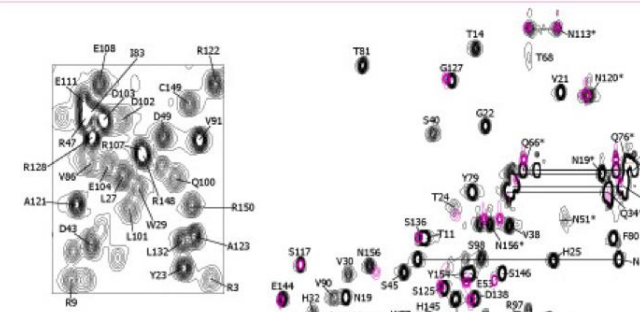
sg 8

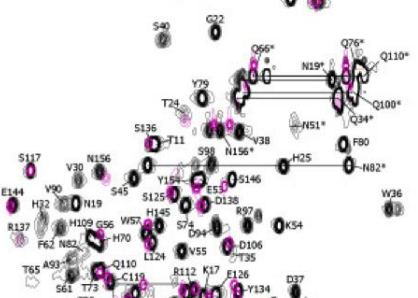

mis

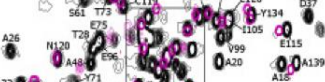

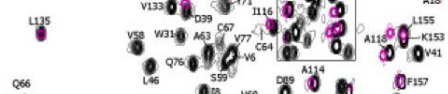

(a)

6

Q

ons

11

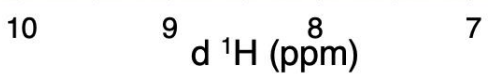

D

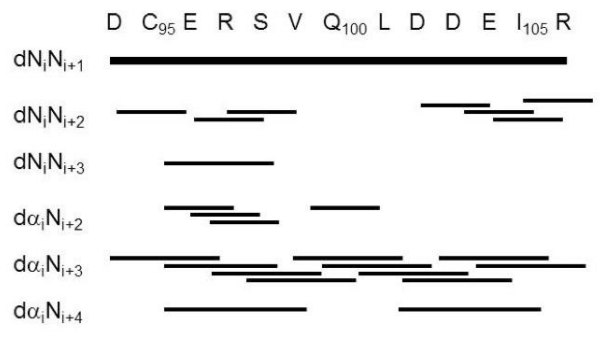

$\mathbf{F}$ T1 (s)

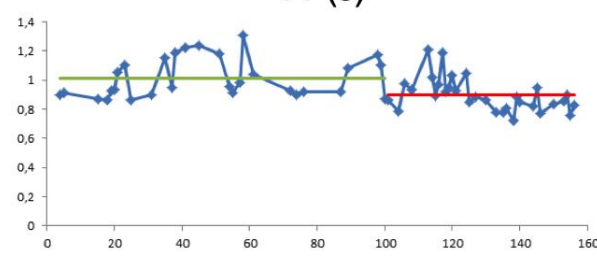

T2 (s)

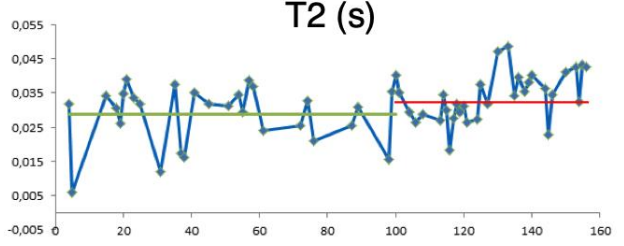


Poignavent et al, Figure 4

\section{Poignavent et al., Figure 4}

A

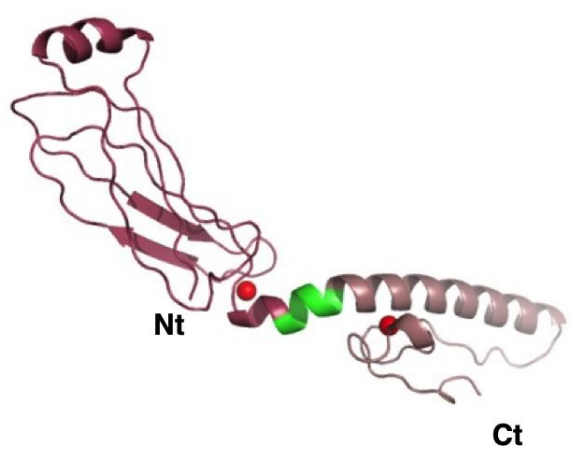

C

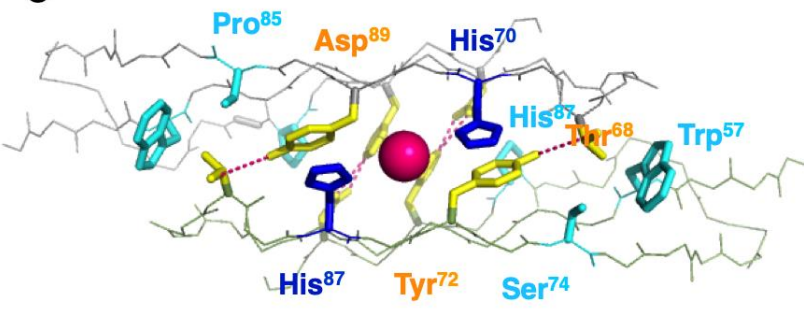

E

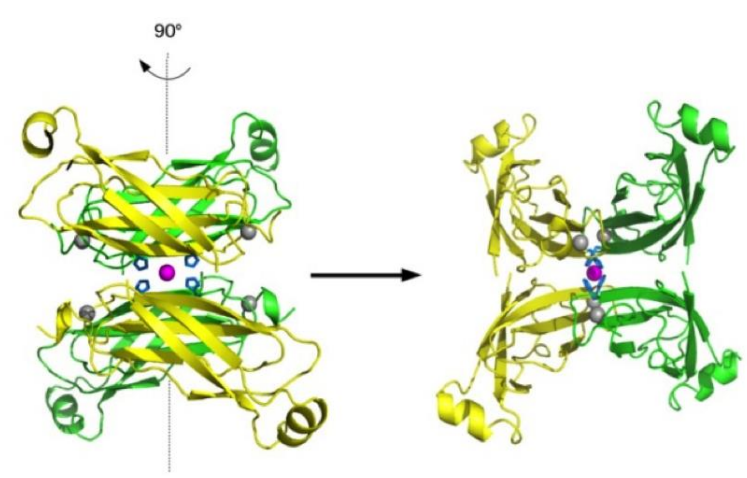

$\mathbf{F}$

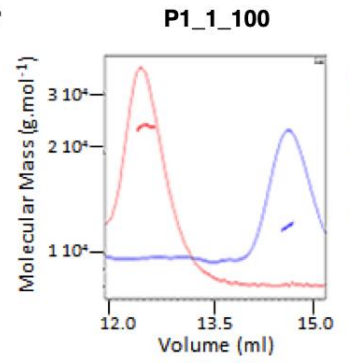

P1_1 157

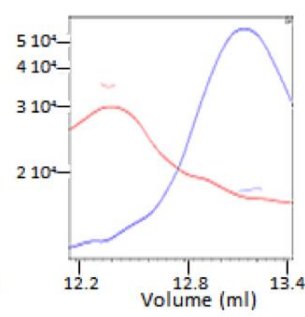

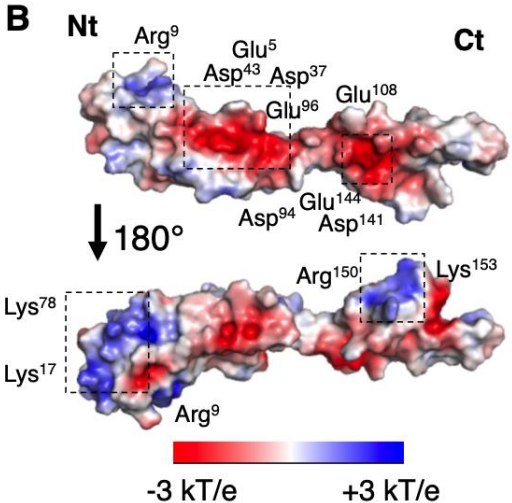

D

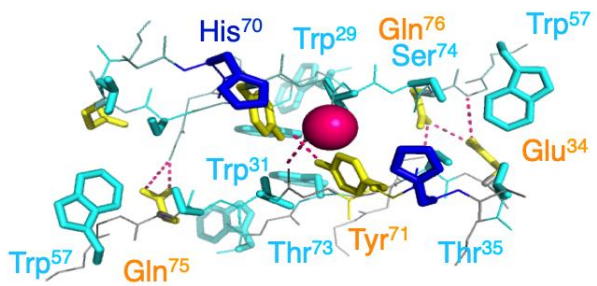

G

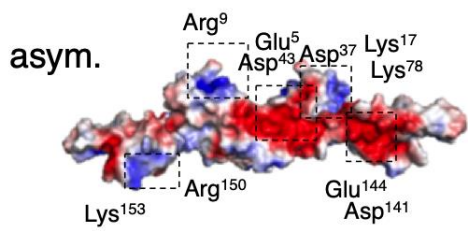

cryst.
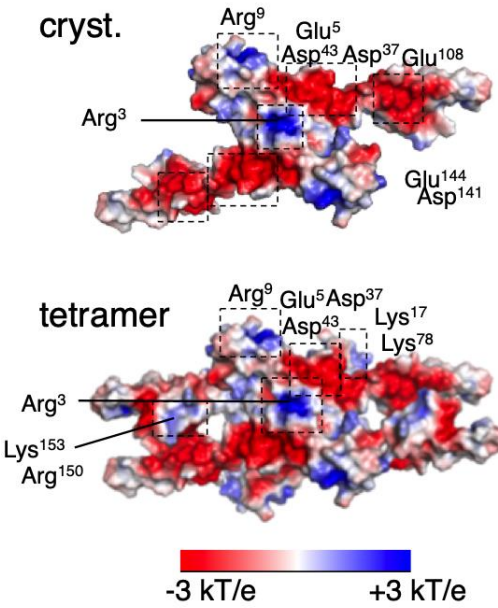
Poignavent et al, Figure 5

A
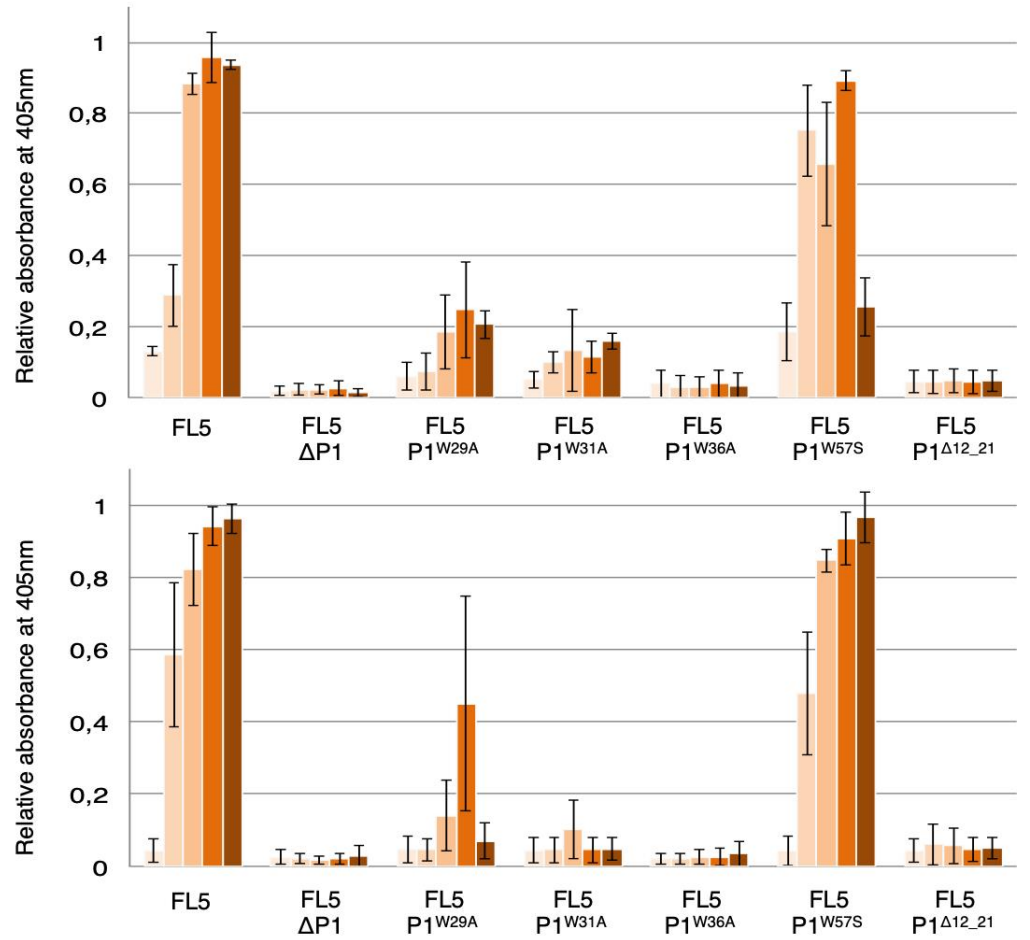

B

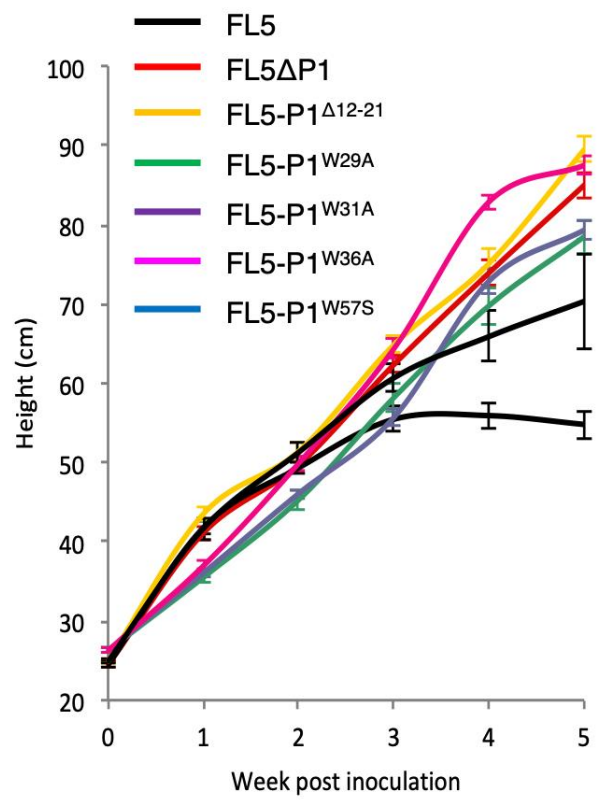

C

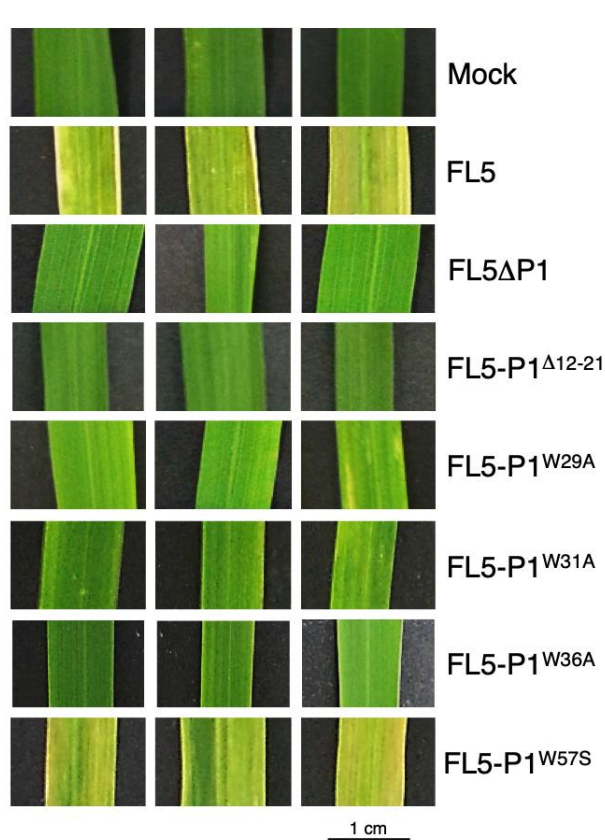


Poignavent et al, Figure 6
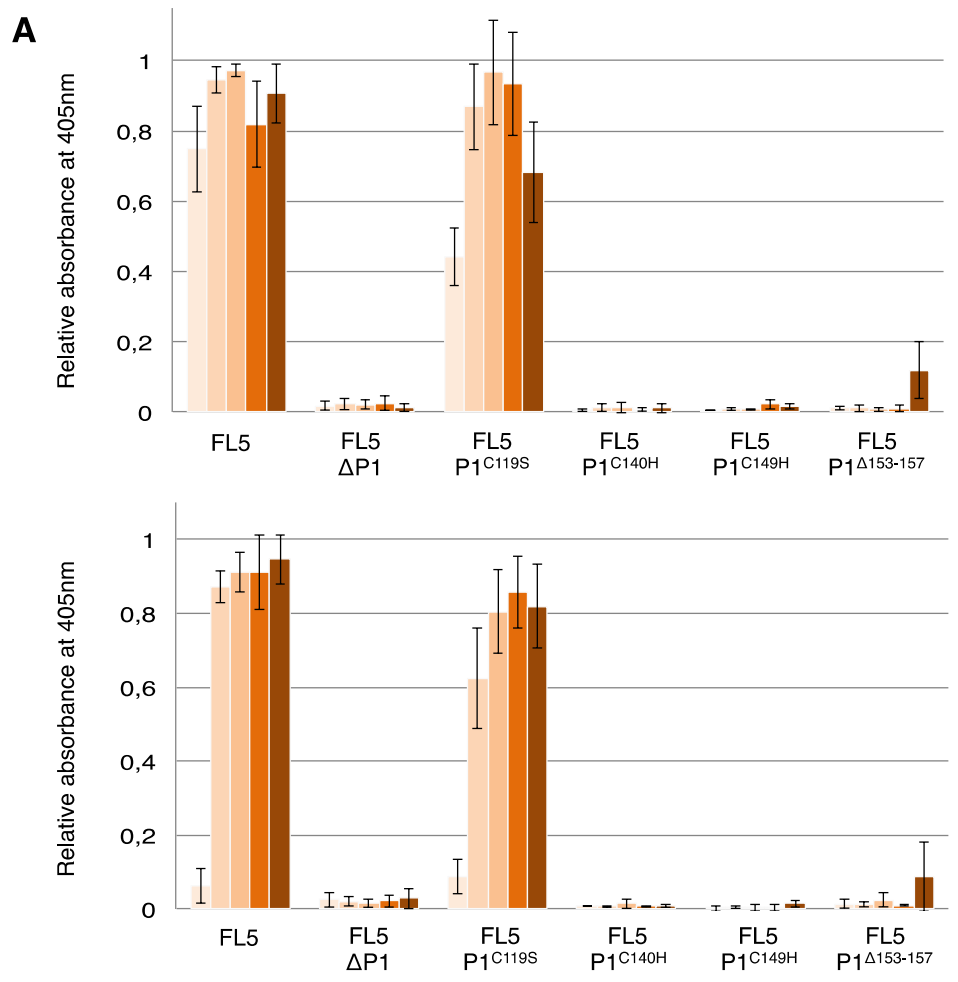

B

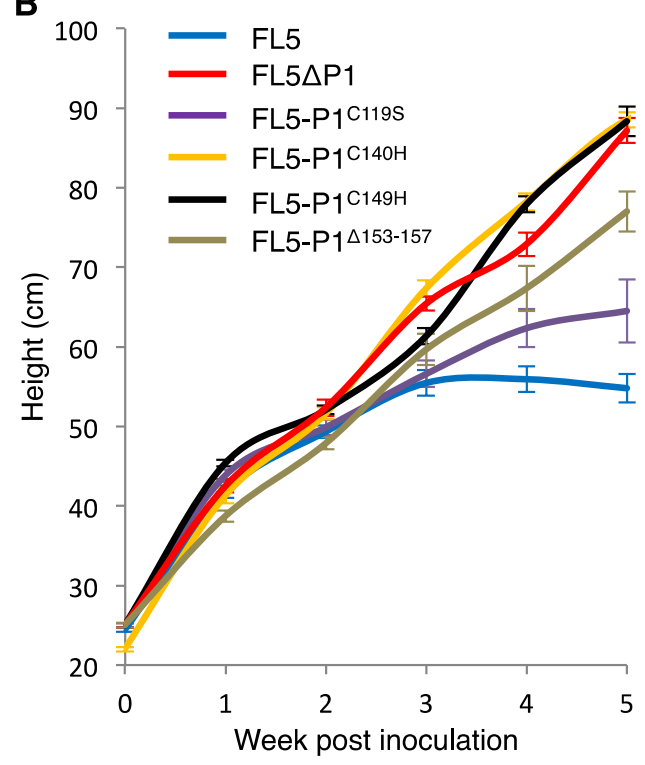

C

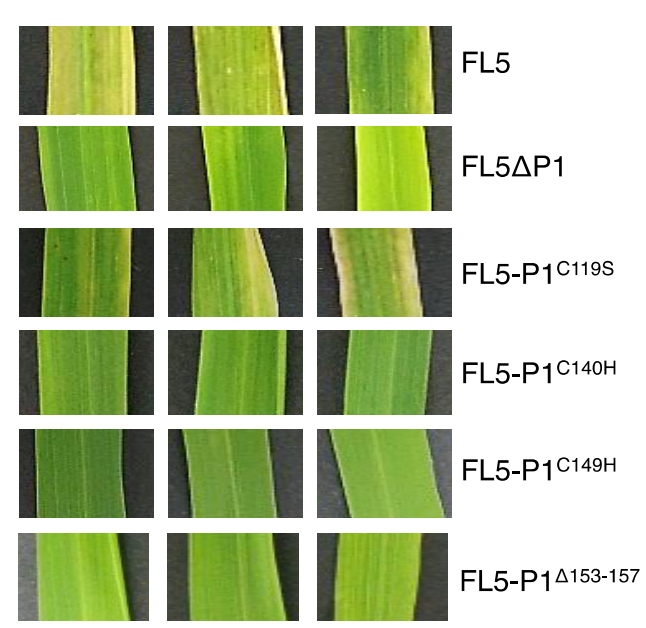




\section{Figure legends.}

\section{Figure 1. The viral RYMV P1 protein binds two zinc atoms at its central and C-terminal regions.}

A Schematic representation of P1 regions designed for production of recombinant proteins in $E$. coli BL21. Cys and His residues outside or inside cysteine-rich regions (CRR) are positioned along the P1 scheme with yellow and red bars respectively. Predicted secondary structures are represented by dark grey arrows for $\beta$-sheets and by light grey squares for $\alpha$-helices. Resizing the full-length P1 protein into different sub regions is represented by thick black lines under the predicted secondary structure, with related P1 region names referring to the size of each truncated protein (amino acids numbering).

B In-gel co-localization of zinc with P1 recombinant sub regions. Purified recombinant proteins were separated on non-reducing SDS-PAGE 18\%. Zinc detection was performed by gel incubation in a Tris $50 \mathrm{mM} \mathrm{pH} 8$ buffer containing the PAR probe (mid panel) before staining by Coomassie blue (upper panel). All proteins assayed were recognized by purified anti-P1 antibody used at a 1:1000 dilution in an immunoblot assay (lower panel).

Table 1. Quantification of zinc atoms in P1 recombinant sub regions and incidence of EDTA treatments on Zinc release.

The incidence of EDTA treatments on P1 sub domains was analyzed by native ESI-MS. The molecular mass determined in Daltons for each isomer is compared to that obtained using denaturing ESI-MS and to theoretical values determined based on the primary sequence of each P1 sub region (Appendix Fig S4). Only values from major forms without zinc, or with one or two zinc atoms of the different isomers comprising the N-terminal methionine are given. Deconvoluted ESI mass spectra for the different proteins are given in the Appendix Fig S5 and Appendix Fig S6. Both P1_50-100 and P1_50-157 proteins underwent immediate degradation after EDTA treatments, independent of the concentrations used and did not produce any signal during ESI-MS analyses.

\section{Figure 2. Crystallographic structure of P1 N- and C-terminal regions.}

A The crystal structure of P1_1-100 (N-terminal region) reveals a dimer in an anti-parallel configuration. Each monomer contains a zinc coordination site constituted by the four cysteines Cys64, Cys67, Cys92 and Cys95 (Cys treble-clef). In addition, a zinc atom (represented as a pink sphere in all panels) is also present at the dimer interface, where it is chelated by the His70 side chain (dark blue sticks) of each monomer. $\mathrm{Nt}$ and $\mathrm{Ct}$ labels point to the $\mathrm{N}$-terminal and $\mathrm{C}$ terminal parts of P1_1-100, respectively.

B Close-up of the Cys-treble clef of P1_1-100, with the side chains of zinc-chelating cysteine residues in stick representation. 
C Schematic diagram representation of P1_1-100 structure. Helices and $\beta$-sheets are depicted as cylinders and arrows, respectively. Cys residues chelating the zinc atom are represented as blue plain circles.

D Each monomer of P1_1-100 presents a small helix with a Lysine side chain residue (Lys17) completely solvent exposed and tolerating only Lys to Arg substitutions. The helix position is stabilized by contacts of hydrophobic residues (side chains represented as grey dotty spheres) which interact with the protein core, and by a network of hydrogen bonds involving the conserved Thr14, Gln13 and Thr11 residues.

E Cartoon representation of P1_102-157 ribbon. Side chains of conserved positively charged and aromatic residues are depicted in stick representation, in green and yellow respectively. The side chains of the HCHC ZnF2 are colored in blue.

F Close-up of the HCHC ZnF2 in P1_102-157, with the side chains of zinc-chelating cysteine and histidine residues in stick representation.

Table 2. Data collection and refinement statistics.

Figure 3. NMR characterization of P1 fragments and full structure.

A Superposition of fingerprint regions of ${ }^{1} \mathrm{H}^{-15} \mathrm{~N}$ HSQC of full length P1_1-157 (black cross peaks) and P1_1-100 (red cross-peaks). Sequence specific resonance assignments are indicated by number for the backbone amide atoms and the one-letter amino acid code. Pairs of side-chain $\mathrm{NH}_{2}$ resonances are connected by horizontal lines. Tryptophan side chain indole peaks are also indicated with asterisks $(*)$.

B Superposition of fingerprint regions of ${ }^{1} \mathrm{H}^{-15} \mathrm{~N}$ spectra HSQC of full length P1_1-157 (black cross peaks) and P1_102-157 (magenta cross-peaks). Sequence specific resonance assignments are indicated by the one-letter amino acid code and the residue number. Pairs of side-chain $\mathrm{NH}_{2}$ resonances are connected by horizontal lines. Tryptophan side chain indole peaks are also indicated with asterisks (*).

C Superposition of fingerprint regions of ${ }^{1} \mathrm{H}^{-15} \mathrm{~N}$ spectra HSQC of ${ }^{15} \mathrm{~N}$-labelled P1_102-157 (c= $0.5 \mathrm{mM}$ ) alone (blue) and in the presence of 2 equivalents of non labeled P1_1-100 (c=1 mM). The resonances of the P1_102-157 are identical in terms of line width and position, supporting the lack of interaction between domains.

D Sequential and medium range NOEs reported between proton atoms for the linker sequence (amino acids 94-106) characterizing their folding into a helix.

E $\quad{ }^{1} D_{\text {HN }}$ residual dipolar couplings measured for full-length P1_1-157 in phage medium depicted as a function of the protein sequence. The positions of P1_1-100 and P1_102-157 regions are indicated as grey segments, with maximal ${ }^{1} \mathrm{D}_{\mathrm{HN}}$ values of the P1_1-100 domain enlightened by dotted lines. The P1_102-157 domain exhibits several ${ }^{1} \mathrm{D}_{\mathrm{HN}}$ below and above these threshold 
values, showing that both regions exhibit different alignment properties. The individual $\chi^{2}$ for each amino acid i: (Dcalc(i)-Dexp(i) $)^{2} / \Sigma_{\text {tot }} \operatorname{Dexp}(\mathrm{i})^{2}$ is also represented on the bottom line.

F $\quad{ }^{15} \mathrm{~N} \mathrm{~T}_{1}$ and $\mathrm{T}_{2}$ relaxation times recorded for full-length $\mathrm{P} 1 \_1-157$, as a function of residue number. The mean values for P1_1_100 and P1_102-157 domains are depicted as green and red horizontal lines, respectively. The differences observed support a significant degree of flexibility between them.

\section{Figure 4. Structure of full-length P1 and oligomerization states by NMR.}

A Model of full-length P1_1-157 built from rigid-body calculations based on the crystallographic structures of individual P1 domains and NMR restraints. The missing segment in crystallographic structures in the linker region has been reconstructed on the basis of NMR restraints; it adopts a helicoidal fold (green portion) extending the long helix of the second zinc finger.

B Electrostatic surface potential representation of the full length P1, showing on one side a large central negatively charged surface and on the other side, two extremal positive poles. Conserved positive and negative patches among the reported $51 \mathrm{P} 1$ sequences are framed.

C Dimer interface of the asymmetric unit. The central $\mathrm{Zn}$ atom is represented as a pink sphere, chelated by His70 (dark blue) in stick representation. Side chains of residue involved in polar and hydrophobic contacts in the dimeric interface are represented in stick and are colored in yellow and cyan blue, respectively.

D Dimer interface of the crystallographic dimer. The central $\mathrm{Zn}$ atom is represented as a pink sphere, chelated by His70 (dark blue) in stick representation. Side chains of residues involved in polar and hydrophobic contacts in the dimeric interface are represented as stick colored in yellow and cyan blue, respectively.

E Cartoon representation of the P1-Nt tetramer (UA in green). Central $\mathrm{Zn}$ atom is represented in magenta and chelating His70 residues, as blue, stick form balls.

F Zinc-dependent oligomerization of the P1_1-100 and full length P1_1-157 proteins. SEC MALLS profile of the P1_1-100 and full length P1_1-157 is depicted. UV absorbance is shown in red in buffer containing zinc and in blue otherwise, as a function of the eluted volume. Calculated masses are represented on the Y-axis.

G Representation of the electrostatic surface of the asymmetric P1 dimeric model (above), of P1 crystallographic dimer (middle) and of tetrameric (below) P1. Conserved positive and negative patches are framed.

Figure 5. Incidence of mutations in P1 N-terminal region residues on RYMV infectivity in rice.

A Consequences of alpha helix [12-21] deletion and of tryptophan residue mutations in P1 on RYMV particle accumulation in rice. Viral charge of rice plantlets infected by FL5-P1 ${ }^{\Delta 12-21}$, 
FL5-P1 ${ }^{\mathrm{W} 29 \mathrm{~A}}$, FL5-P1 ${ }^{\mathrm{W} 31 \mathrm{~A}}$, FL5-P1 ${ }^{\mathrm{W} 36 \mathrm{~A}}$, and FL5-P1 ${ }^{\mathrm{W} 57 \mathrm{~S}}$ RNAs was recorded by DAS-ELISA on total proteins extracted from inoculated (upper panel) and systemic (lower panel) leaves collected every week during 5 weeks (light to dark bars). An antibody directed against the RYMV coat protein CP was used in DAS-ELISA for the detection of viral particles neosynthesized. The original infectious clone FL5 (Brugidou et al, 1995) and its non-infectious version FL5 $\Delta \mathrm{P} 1$ (Appendix Fig S16) were used as positive and negative controls for infection and viral systemic spread, respectively.

B Plant height (in $\mathrm{cm}$ ) of inoculated plants recorded all along the 5-week infection process.

C Yellowing symptom recording at the leaf surface of inoculated plants. Three samples of rice leaves are show as representative of symptoms visible at the overall plant scale. Leaves were photographed 5 weeks post inoculation.

Data information: The first 3 leaves of 14-day old rice plantlets were selected for inoculation by synthetic viral RNA or by RYMV particles, while the following ones from the $4^{\text {th }}$ leaf corresponded to systemic tissues. Synthetic FL5-derived RNAs (5 $\mu \mathrm{g})$ were used in a phosphate/carborandum buffer for inoculation, while mock plants were treated similarly but without RYMV-derived molecules (Appendix Supplementary Materials). All data were obtained from 30 plants per treatment, in two independent inoculation assays.

\section{Figure 6. Incidence of mutations in P1 C-terminal region residues on RYMV infectivity in rice.}

A Consequences of cysteine and histidine residue mutations in P1, and of the deletion of P1 hydrophobic tail (residues [153-157]) on RYMV particle accumulation in rice. The viral charge of rice plantlets infected by FL5-P1 ${ }^{\mathrm{H} 109 \mathrm{~A}}$, FL5-P1 ${ }^{\mathrm{C} 119 \mathrm{~S}}$, FL5-P1 ${ }^{\mathrm{C} 140 \mathrm{H}}$, FL5-P1 ${ }^{\mathrm{C} 149 \mathrm{H}}$, and FL5P1 ${ }^{\Delta 153-157}$ RNAs were recorded by DAS-ELISA on total proteins extracted from inoculated (upper panel) and systemic (lower panel) leaves collected every week during 5 weeks (light to dark bars). An antibody directed against the RYMV coat protein CP was used in DAS-ELISA for the detection of neo-synthesized viral particles. The original infectious clone FL5 (Brugidou et $a l, 1995$ ) and its non-infectious version FL5 $\Delta \mathrm{P} 1$ (Appendix Fig S16) were used as positive and negative controls for infection and viral systemic spread, respectively.

B Plant height (in $\mathrm{cm}$ ) of inoculated plants recorded all along the 5-week infection process.

C Yellowing symptom recording at the leaf surface of inoculated plants. Three samples of rice leaves are show as representative of symptoms visible at the overall plant scale. Leaves were photographed 5 weeks post inoculation.

Data information: An antibody directed against the RYMV coat protein CP was used in DAS-ELISA for the detection of neo-viral particles. Mock plants corresponding to rice plantlets inoculated with a buffer free of RYMV particles or FL5-derived RNAs also served as healthy plant controls for both height measurements and symptom recording. All data were obtained from 30 plants per treatment, in two independent inoculation assays. 